Article

\title{
An Integrated Best-Worst and Interval Type-2 Fuzzy TOPSIS Methodology for Green Supplier Selection
}

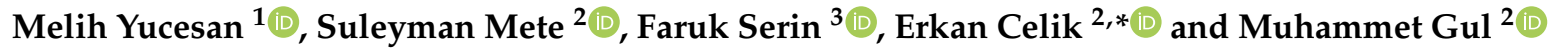 \\ 1 Munzur University, Faculty of Engineering, Department of Mechanical Engineering, 62000 Tunceli, Turkey; \\ melihyucesan@munzur.edu.tr \\ 2 Munzur University, Faculty of Engineering, Department of Industrial Engineering, 62000 Tunceli, Turkey; \\ suleyman489@gmail.com (S.M.); muhammetgul@munzur.edu.tr (M.G.) \\ 3 Munzur University, Faculty of Engineering, Department of Computer Engineering, 62000 Tunceli, Turkey; \\ fserin@munzur.edu.tr \\ * Correspondence: erkancelik@munzur.edu.tr
}

Received: 29 December 2018; Accepted: 31 January 2019; Published: 15 February 2019

check for updates

\begin{abstract}
Supplier selection is one of the most important multi-criteria decision-making (MCDM) problems for decision-makers in the competitive market. Today's organizations are seeking new ways to reduce the negative effects they have on the environment and to achieve a greener system. Currently, the concept of green supplier selection has gained great importance for its ability to incorporate environmental or green criteria into classical supplier selection practices. Therefore, in this study, a multi-phase MCDM model based on the best-worst method (BWM) and the interval type-2 fuzzy technique for order preference by similarity to ideal solution (IT2F TOPSIS) is proposed. A case study in a plastic injection molding facility in Turkey was carried out to show the applicability of the proposed integrated methodology. The paper offers insights into decision-making, methodology, and managerial implications. Results of the case study are examined and suggestions for future research are provided.
\end{abstract}

Keywords: MCDM; BWM; interval type-2 fuzzy sets; TOPSIS; green supplier selection; plastic injection molding

\section{Introduction}

Supply chain management (SCM) includes the creation of information and material flows, production scheduling, and the planning of distribution systems [1]. Adding value to supply chain management is crucial for today's businesses in order to improve organizational performance and provide a competitive advantage. This is necessary because competition no longer exists solely between institutions, but also in the area of SCM. SCM focuses not only on material resources but also on values such as knowledge. Information has become the most important source of SCM [2,3]. SCM builds an integrated approach by analyzing manufacturers, warehouses, production, and suppliers. Thus, enterprises produce and distribute products at the appropriate time and in appropriate quantities. SCM implements an entire system approach while managing materials and services. Decision-makers attach importance to the management of internal operations in order to increase the productivity of the enterprises. SCM requires the integration of internal and external activities in enterprises. With increasing global competition, the quality and price gaps between products are closing every day. Therefore, supplier selection is one of the most important multi-criteria decision-making (MCDM) problems for enterprises [4,5]. Choosing an appropriate supplier is one of the most important processes under the responsibility of the purchasing department. On the other hand, practices aimed at protecting the environment are gaining importance both in the private and public sectors. As environmental 
awareness increases, an environmentally-friendly approach also becomes an inevitable element in supply chain management applications. Currently, final consumers also consider environmentally sensitive products in their procurement processes.

The aim of green supply chain management (GSCM) is to minimize pollution and other factors affecting the environment. It helps suppliers recognize the significance of resolving environmental issues. In addition, GSCM helps enterprises achieve a balance between environmental and economic performance, thereby reducing the impact of their products and fostering an environmental image and environmentally friendly services. GSCM strives to increase the use of green products and encourage businesses to increase the market share of such products. In addition to traditional goals, GSCM also aims to establish and develop an environmentally friendly supply chain system. Therefore, environmental criteria should be used together with traditional criteria in selecting green suppliers. However, most of the green supplier selection studies in the literature are based on environmental criteria. The main criteria for the development of suppliers are green information transfer, investment and resource transfer, as well as management and organization practices. In the portfolio-based analysis, pollution prevention and avoidance of pollution are considered as major differences in the selection of green suppliers [6]. Some studies have also used criteria such as GSCM capabilities, strategic level of the procurement department, environmental commitment level, or degree of green supplier evaluation and cooperation. In the green purchasing process, regulation, customer pressure, social responsibility, and commercial benefits are among the most commonly used criteria [7].

This paper proposes an integrated best-worst and IT2F TOPSIS methodology for green supplier selection in the plastic injection molding industry. The methodology introduced for the selection of green suppliers was carried out under three phases. First, the selection criteria following the green concept were determined through a literature review and interviews with decision-makers. In the second phase, criteria weights were determined using best-worst method (BWM). Finally, to prioritize suppliers with respect to the weighted criteria, an IT2F TOPSIS method was utilized. This study is considered as the first attempt at integrating BWM and IT2F TOPSIS to obtain supplier selection knowledge. Since BWM is easier and more efficient than analytic hierarchy process (AHP) for pairwise comparisons, it was used in weighting the selection criteria. The use of the TOPSIS method extended with interval type-2 fuzzy sets (IT2FSs) allowed more uncertainty and ambiguity to be reflected in the decision-making process as well as including the concept of similarity to ideal solution.

The proposed approach was applied to the plastic injection molding industry to select a green supplier. The plastic injection products have been broadly used in high-tech commodities and different household necessities. In this regard, pipe and fitting production technology and raw material usage are intensive. In addition, the competition conditions of this production area are very fierce. Hence, choosing the right supplier plays a vital role in the success of the enterprises. There are few methods and studies covered in the literature for this area. Therefore, this paper proposes a multi-phase MCDM model to select which supplier is well-suited to the pipe manufacturing enterprise. The case design approach was carried out by incorporating data provided by a district -based small- and medium-sized enterprise. Specifically, the main contributions of this paper are summarized as follows: (i) An integrated approach based on best-worst and IT2F TOPSIS methodology was proposed. (ii) A case study was carried out for the plastic injection molding industry. This case study highlighted the implications of the methodology for the industry and the methodology followed can be easily adapted to another sector in this regard. (iii) IT2FSs were combined with BWM for the first time in the literature. As a result, uncertainty in the decision-making process can be clearly reflected as compared to type-1 fuzzy set theory [8-12].

The rest of the paper is presented as follows: A literature review regarding supply chain management and supplier selection is presented in the next section. The best-worst method is described and analyzed in Section 3. In Section 4, a case study is presented to help understand the proposed method, carried out for green supplier selection in an injection molding facility in Turkey. Finally, conclusions and directions for future research are presented in Section 5. 


\section{Literature Review}

The literature review section is divided into two subsections. First, literature regarding green supplier selection is analyzed, then literature related to the best-worst method is addressed. Many studies related to green supplier selection and evaluation were found in the literature. Supplier selection can be defined as one of the most important phases in supply management function and purchasing [13]. A variety of MCDM methods have recently been used by researchers to deal with green supplier selection problems. In the literature, different supplier selection criteria were used such as quality, delivery, and cost for evaluating their suppliers [14]. A number of environmental factors were considered to select green suppliers [15]. Criteria such as pollution production [16,17], recycling utilization level of waste material [18], level of clean energy utilization [19], noise level [20], and level of environmental protection input [21] were considered by researchers. On the other hand, individual and hybrid methods were proposed for determining supplier selection in the literature [22]. A grey analytical network process (ANP)-based model to determine green supplier development programs to develop the performance of suppliers was introduced by [23]. The model was tested on real-world examples to show model effectiveness [24]. They proposed a preference ranking organization method for enrichment evaluation (PROMETHEE) method based on a hybrid multiple criteria decision-making approach to develop green supplier performance. A fuzzy axiomatic design approach was introduced to choose the best green supplier for a plastic manufacturing company in Singapore [16]. The requirements of the manufacturer and the supplier were evaluated using a proposed methodology with a multi-objective optimization model and fuzzy nature. Hashemi et al. [25] considered environmental and economic criteria and introduced a model based on improved grey relational analysis (GRA) and ANP for comprehensive green supplier selection. Uygun and Dede [26] proposed an integrated fuzzy MCDM method, which was based on fuzzy decision-making trial and evaluation laboratory (DEMATEL), fuzzy ANP, and fuzzy TOPSIS, to evaluate and select green suppliers by considering green purchasing, green design, green logistics, and reverse logistics. Yazdani et al. [19] designed a green supplier selection model. The proposed model focused on the interrelationships between the requirements of the customer with a DEMATEL method when constructing a relationship structure. Moreover, quality function deployment was used to determine the degree of relationship for the criteria of supplier selection pairs. Recently, three popular multi-criteria supplier selection applications, namely, TOPSIS, GRA, and Vise Kriterijumska Optimizacija I Kompromisno Resenje (VIKOR), were compared to each other by [13] under fuzzy environment. The method was applied to an actual company from the agri-food industry for green supplier evaluation and selection. Yu et al. [15] proposed a model based on the carbon footprint, including environmental and economic attributes to select a green supplier with a dynamic environment. Moreover, a literature review related to green supplier selection and estimation methods can be found in $[27,28]$.

On the other hand, the best-worst method was first introduced by [29] to solve MCDM problems. In this method, many alternatives are considered according to different criteria in order to choose the best alternative. According to this method, two of the criteria, which are the best or most important criteria and the worst or least important criteria, are determined by the decision-maker. The method is a novel approach and has been applied to different research areas due to BWM's flexibility and simplicity for solving problems. Rezaei et al. [30] applied BWM to supplier segmentation to find the relative weight of the criteria. Then, the method was applied to different research areas, such as supplier selection [31,32], multi-criteria decision-making [17,33], evaluating freight bundling configurations [34], and assessment of other factors affecting sustainability in SCM [35]. Guo and Zhao [36] proposed the BWM technique with MCDM under fuzzy environment. Van de Kaa et al. [37] used the BWM technique and expert opinions for calculating the relative importance of factors to evaluate and rank technologies. The method was applied to the technology battle for biomass conversion in the Netherlands. Omrani et al. [38] proposed an integrated approach including Taguchi-neural network BWM and TOPSIS under fuzzy environment. The proposed integrated approach was applied to a case study to find the optimal combination of different power plants. 
In light of the above, this paper aims to fill the gap in the literature for an integrated best-worst and IT2F TOPSIS methodology for green supplier selection in the plastic injection molding industry in Turkey.

\section{Materials and Methods}

\subsection{The Evaluation Criteria for Green Supplier Selection}

Within the context of green supplier selection, the recent review of [27] identified Environmental Management Systems (EMS) as the most popular environmental criteria due to its flexibility. Nielsen et al. [39] reviewed 57 related papers and, like Govindan et al. [27], found EMS the most important and comprehensive environmental criteria amongst over 90 identified measures. Using these reviews and the identified criteria, a combination of conventional and green supplier selection criteria is used in our study for the purpose of supplier assessment. The criteria used in relevant literatures are listed in Table 1.

Table 1. The used criteria in literature for supplier selection.

\begin{tabular}{|c|c|c|c|c|c|c|c|c|}
\hline Study/Criteria & C1-Environmental. & C2-Social & C3-Quality & C4-Service & C5-Risk & C6-Cost/Price & C7-Capability & C8-Business structure \\
\hline Kahraman et al. [40] & & & $x$ & $x$ & & $x$ & & \\
\hline Büyüközkan and Çiftçi [41] & & & $x$ & $x$ & & $x$ & & \\
\hline Chiou et al. [42] & & & & $x$ & $x$ & $x$ & & \\
\hline Demirtas and Ustun [43] & & & $x$ & $x$ & & $x$ & $x$ & \\
\hline Lee [44] & & & $x$ & $x$ & $x$ & $x$ & $x$ & \\
\hline Lin et al. [45] & & & $x$ & $x$ & & $x$ & & \\
\hline Liou and Chuang [46] & & & $\mathrm{x}$ & $x$ & & $x$ & & \\
\hline Liu et al. [47] & & & $x$ & $x$ & $x$ & $x$ & $x$ & \\
\hline Liu et al. [48] & & & $x$ & $x$ & $x$ & $x$ & & \\
\hline Luthra et al. [49] & & & $x$ & $x$ & & $x$ & $x$ & \\
\hline Malmir et al. [50] & & & $x$ & $x$ & $x$ & $x$ & $x$ & \\
\hline Razmi et al. [51] & & & $x$ & $x$ & $x$ & $x$ & $x$ & $x$ \\
\hline Da Silva et al. [52] & & & $\mathrm{x}$ & $x$ & & $x$ & $x$ & \\
\hline Vinodh et al. [53] & & & $x$ & $x$ & $x$ & $x$ & & \\
\hline Wadhwa and Ravindran [54] & & & $x$ & & $\mathrm{x}$ & $x$ & & $x$ \\
\hline Wang et al. [55] & & & $x$ & & & $x$ & & \\
\hline Attari et al. [56] & & & $x$ & & & $x$ & & $x$ \\
\hline Haq and Kannan [57] & & & $x$ & & & $x$ & & $x$ \\
\hline Prahinsk and Benton [58] & & & $x$ & & & $x$ & & \\
\hline Chiou et al. [42] & $x$ & $x$ & $x$ & & & $x$ & & \\
\hline Freeman and chen [59] & $x$ & $x$ & $x$ & & $x$ & $x$ & & \\
\hline Hsu et al. [60] & $x$ & $x$ & $x$ & & $x$ & & & \\
\hline Kuo et al. [61] & $x$ & $x$ & $x$ & & & $x$ & & $x$ \\
\hline
\end{tabular}

\subsection{Best-Worst Method}

The best-worst method (BWM) was introduced for the choice phase [29]. The BWM is characterized by some salient features such as (i) it provides a very structured pairwise comparison, which results in highly consistent and reliable results; (ii) it uses only two vectors instead of a full pairwise comparison matrix. This implies less data collection effort, taking less time from the analyst and the decision-maker. Interestingly, as these two vectors are more structured than a full matrix, less data here leads to more reliability; (iii) the method uses only integer values, which makes it more practically understandable compared to methods utilizing fractions [31].

Step 1. Determine a set of decision criteria. In this step, we consider the criteria (c_1, c_2 . . , c_n) that should be used to arrive at a decision.

Step 2. Determine the best (e.g., most desirable, most important) and the worst (e.g., least desirable, least important) criteria. In this step, the decision-maker identifies the best and the worst criteria in general. No comparison is made at this stage. 
Step 3. Determine the preference of the best criterion over all the other criteria using a number between 1 and 9. The resulting Best-to-Others vector would be:

$$
A_{B}=\left(a_{B 1}, a_{B 2}, \ldots, a_{B n}\right),
$$

where $a_{B j}$ indicates the preference of the best criterion B over criterion j. It is clear that $a_{B B}=1$.

Step 4. Determine the preference of all the criteria over the worst criterion using a number between 1 and 9. The resulting Others-to-Worst vector would be

$$
A_{B}=\left(a_{1 W}, a_{2 W}, \ldots, a_{n W}\right)^{T}
$$

where $a_{j W}$ indicates the preference of the criterion $\mathrm{j}$ over the worst criterion $W$. It is clear that $a_{W W}=1$.

Step 5. Find the optimal weights $\left(w_{1}^{*}, w_{2}^{*}, \ldots, w_{n}^{*}\right)$.

The optimal weight for the criteria is the one where, for each pair of $w_{B} / w_{j}$ and $w_{j} / w_{w}$ we have $w_{B} / w_{j}=a_{j w}$. To satisfy these for all $j$, we should find a solution where the maximum absolute differences $\left|\frac{w_{B}}{w_{j}}-a_{B j}\right|$ and $\left|\frac{w_{j}}{w_{W}}-a_{j W}\right|$ for all $j$ is minimized. Considering the non-negativity and sum condition for the weights, the following problem is resulted:

$$
\begin{aligned}
& \underset{j}{\operatorname{minmax}}\left\{\left|\frac{w_{B}}{w_{j}}-a_{B j}\right|,\left|\frac{w_{j}}{w_{W}}-a_{j W}\right|\right\} \\
& \text { s.t } \\
& \sum w_{j}=1 \\
& w_{j} \geq 0 \text { for all } j
\end{aligned}
$$

Problem can be transferred to the following problem: $\xi$

$\min \xi$

$$
\begin{aligned}
& \left|\frac{w_{B}}{w_{j}}-a_{B j}\right| \leq \xi \text { for all } j \\
& \left|\frac{w_{j}}{w_{W}}-a_{j W}\right| \leq \xi \text { for all } j \\
& \sum w_{j}=1 \\
& w_{j} \geq 0, \text { for all } j
\end{aligned}
$$

Solving problem, the optimal weights $\left(w_{1}^{*}, w_{2}^{*}, \ldots, w_{n}^{*}\right)$ and $\xi^{*}$ are calculated. After that consistency ratio is calculated with consistency index (Table 2). It becomes clear that, the bigger the $\xi^{*}$, the higher the consistency ratio, and the less reliable the comparisons become.

Table 2. Consistency Index.

\begin{tabular}{cccccccccc}
\hline $\boldsymbol{a}_{\boldsymbol{B} W}$ & $\mathbf{1}$ & $\mathbf{2}$ & $\mathbf{3}$ & $\mathbf{4}$ & $\mathbf{5}$ & $\mathbf{6}$ & $\mathbf{7}$ & $\mathbf{8}$ & $\mathbf{9}$ \\
\hline consistency index & 0.00 & 0.44 & 1.00 & 1.63 & 2.30 & 3.00 & 3.73 & 4.47 & 5.23 \\
\hline
\end{tabular}

\subsection{IT2F TOPSIS}

TOPSIS approach aims to choose alternatives that simultaneously have the shortest distance from the positive ideal solution and the farthest distance from the negative-ideal solution [62-64]. IT2F TOPSIS, [65] Pythagorean fuzzy TOPSIS [66]. Ak and Gul [67] are developed as different versions of TOPSIS based on fuzzy sets. TOPSIS based on IT2FSs reflects uncertainty, vagueness, and ambiguity using advantages of IT2FSs $[65,68-72]$ better than ordinary fuzzy TOPSIS. The proposed TOPSIS based on IT2FSs can be applied via a series of steps:

Step 1: Assume that there is a set $S$ of alternatives, where $S=\left\{s_{1}, s_{2}, \ldots, s_{n}\right\}$, and assume that there is a set $C$ of criteria, $C=\left\{c_{1}, c_{2}, \ldots, c_{m}\right\}$ and there are $K$ decision-makers $D=\left\{D_{1}, D_{2}, \ldots, D_{K}\right\}$ Each decision-maker is a participant in our questionnaire and $\mathrm{s} /$ he has her/his own perception value 
regarding the performance of supplier with respect to each criterion. The aggregate performance value of supplier with respect to each criterion can be calculated using Equation (1):

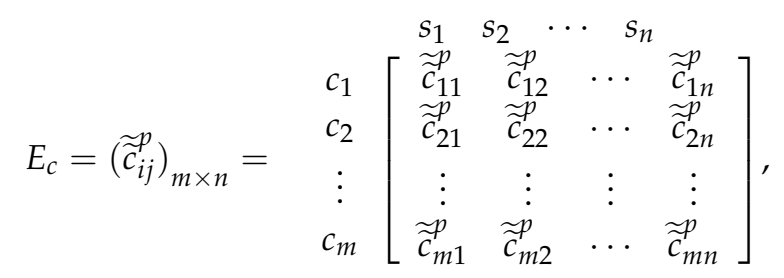

where $\widetilde{\widetilde{c}}_{i j}=\left(\frac{\widetilde{\widetilde{c}}_{i j} \oplus \widetilde{\widetilde{c}}_{i j} \oplus \cdots \oplus \widetilde{\widetilde{c}}_{i j}^{k}}{k}\right), \widetilde{\widetilde{s}}_{i j}$ is an IT2FS $1 \leq i \leq m, 1 \leq j \leq n, 1 \leq c \leq k$ and $k$ denotes the number of expert,

$$
\widetilde{\widetilde{c}}_{i j}=\left(\left(a_{i 1}^{U}, a_{i 2}^{U}, a_{i 3}^{U}, a_{i 4}^{U} ; H_{1}\left(\widetilde{A}_{i}^{U}\right), H_{2}\left(\widetilde{A}_{i}^{U}\right)\right),\left(a_{i 1}^{L}, a_{i 2}^{L}, a_{i 3}^{L}, a_{i 4}^{L} ; H_{1}\left(\widetilde{A}_{i}^{L}\right), H_{2}\left(\widetilde{A}_{i}^{L}\right)\right)\right)
$$

Step 2: Obtain the weighting matrix $W_{s}$ of the criteria using the best-worst method,

$$
W_{s}=\left(w_{i}^{s}\right)_{1 \times m}=\left[\begin{array}{cccc}
c_{1} & c_{2} & \cdots & c_{m} \\
w_{1}^{s}, & w_{2}^{s}, \cdots, & \cdots
\end{array}\right.
$$

Step 3: Calculate the weighted decision matrix by multiplying the importance weights of criteria and the values in the decision matrix. The weighted decision matrix $\widetilde{\widetilde{V}}$ for each criterion is defined as follows:

$$
\widetilde{\widetilde{v}}_{i j}=\widetilde{\widetilde{c}}_{i j} \times w_{i}
$$

where $\widetilde{\widetilde{v}}_{i j}$ denotes the weighted trapezoidal interval type-2 fuzzy numbers.

Step 4: Calculate the ranking value $\operatorname{Rank}\left(\widetilde{\widetilde{v}}_{i j}\right)$ of IT2FSs. The ranking weighted decision matrix $E_{w}$ is constructed.

Step 5: Determine the positive ideal solution $x^{*}=\left(v_{1}^{*}, v_{2}^{*}, \ldots, v_{m}^{*}\right)$ and the negative-ideal solution $x^{-}=\left(v_{1}^{-}, v_{2}^{-}, \ldots, v_{m}^{-}\right)$where

$$
\begin{gathered}
v_{i}^{*}=\left\{\begin{array}{l}
\max _{i \leq j \leq n}\left\{\operatorname{Rank}\left(\widetilde{\widetilde{v}}_{i j}\right)\right\}, \text { if } f_{i} \in B \\
\min _{i \leq j \leq n}\left\{\operatorname{Rank}\left(\widetilde{\widetilde{v}}_{i j}\right)\right\}, \text { if } f_{i} \in C^{\prime}
\end{array}\right. \\
v_{i}^{-}=\left\{\begin{array}{l}
\min _{i \leq j \leq n}\left\{\operatorname{Rank}\left(\widetilde{\widetilde{v}}_{i j}\right)\right\}, \text { if } f_{i} \in B \\
\max _{i \leq j \leq n}\left\{\operatorname{Rank}\left(\widetilde{\widetilde{v}}_{i j}\right)\right\}, \text { if } f_{i} \in C
\end{array}\right.
\end{gathered}
$$

Then, positive $d^{*}\left(x_{j}\right)$ and negative $d^{-}\left(x_{j}\right)$ ideal solutions are determined for green supplier as follows:

$$
\begin{aligned}
d^{*}\left(x_{j}\right) & =\sqrt{\sum_{i \in I}\left(\operatorname{Rank}\left(\widetilde{\widetilde{v}}_{i j}\right)-v_{i}^{*}\right)^{2}} \\
d^{-}\left(x_{j}\right) & =\sqrt{\sum_{i \in I}\left(\operatorname{Rank}\left(\widetilde{\widetilde{v}}_{i j}\right)-v_{i}^{-}\right)^{2}}
\end{aligned}
$$


The ranking value $\operatorname{Rank}\left(\widetilde{\widetilde{A}}_{i}\right)$ of the trapezoidal IT2FS $\widetilde{\widetilde{A}}_{i}$ is defined as follows:

$$
\begin{aligned}
& \operatorname{Rank}\left(\widetilde{\widetilde{v}}_{i}\right)=M_{1}\left(\widetilde{v}_{i}^{U}\right)+M_{1}\left(\widetilde{v}_{i}^{L}\right)+M_{2}\left(\widetilde{v}_{i}^{U}\right)+M_{2}\left(\widetilde{v}_{i}^{L}\right)+M_{3}\left(\widetilde{v}_{i}^{U}\right)+M_{3}\left(\widetilde{v}_{i}^{L}\right) \\
& -\frac{1}{4}\left(S_{1}\left(\widetilde{v}_{i}^{U}\right)+S_{1}\left(\widetilde{v}_{i}^{L}\right)+S_{2}\left(\widetilde{v}_{i}^{U}\right)+S_{2}\left(\widetilde{v}_{i}^{L}\right)+S_{3}\left(\widetilde{v}_{i}^{U}\right)+S_{3}\left(\widetilde{v}_{i}^{L}\right)+S_{4}\left(\widetilde{v}_{i}^{U}\right)+S_{4}\left(\widetilde{v}_{i}^{L}\right)\right) \\
& +H_{1}\left(\widetilde{v}_{i}^{U}\right)+H_{1}\left(\widetilde{v}_{i}^{L}\right)+H_{2}\left(\widetilde{v}_{i}^{U}\right)+H_{2}\left(\widetilde{v}_{i}^{L}\right)
\end{aligned}
$$

where $M_{p}\left(\widetilde{\widetilde{v}}_{i}^{j}\right)$ denotes the average of the elements $v_{i p}^{j}$ and $v_{i(p+1)}^{j}$, denotes the standard deviation of the elements $v_{i p}^{j}$ and $v_{i(p+1)}^{j}, M_{p}\left(\widetilde{\widetilde{v}}_{i}^{j}\right)=\left(v_{i p}^{j}+v_{i(p+1)}^{j}\right) / 2,1 \leq p \leq 3$, denotes the standard deviation of the $v_{i q}^{j}$ and $v_{i(q+1)}^{j}, S_{q}\left(\widetilde{v}_{i}^{j}\right)=\sqrt{\frac{1}{2} \sum_{k=q}^{q+1}\left(v_{i k}^{j}-\frac{1}{2} \sum_{k=q}^{q+1} v_{i k}^{j}\right)^{2}}, 1 \leq q \leq 3, S_{4}\left(\widetilde{v}_{i}^{j}\right)$ denotes the standard deviation of the elements $v_{i 1}^{j}, v_{i 2}^{j}, v_{i 3}^{j}, v_{i 4}^{j}, S_{4}\left(\widetilde{v}_{i}^{j}\right)=\sqrt{\frac{1}{4} \sum_{k=1}^{4}\left(v_{i k}^{j}-\frac{1}{4} \sum_{k=1}^{4} v_{i k}^{j}\right)^{2}} H_{p}\left(\widetilde{v}_{i}^{j}\right)$ denotes the membership value of the element $v_{i(p+1)}^{j}$ in the trapezoidal membership function $\widetilde{v}_{i}^{j}, 1 \leq p \leq 3, j \in\{U, L\}$, and $1 \leq$ $i \leq n$.

Step 6: Then the closeness coefficient $C C\left(x_{j}\right)$ is calculated.

$$
C C\left(x_{j}\right)=\frac{d^{-}\left(x_{j}\right)}{d^{*}\left(x_{j}\right)+d^{-}\left(x_{j}\right)}
$$

Step 7: We can rank alternatives in decreasing order. The larger the value of $C C\left(x_{j}\right)$, the higher the preference of the green supplier.

\section{Case Study}

Injection molding is one of the most common methods in plastic parts production. With this method, complex geometric products can be produced easily. Molding machine, raw plastic material and mold of the product to be produced are required for the production by injection molding. The raw material used in this production method is directly related to the quality of the product. In this respect, supplier choice plays an important role in the success of the operator. The injection molding method consists of four main stages as demonstrated in Figure 1. These stages are drying, blending and dosing, injection molding and regrinding, respectively. In the drying stage, the material (plastic beads and the reusable scrap) is fed into the dryer, to remove or reduce moisture to an acceptable level. In the second stage, material is further mixed with the additives. In the third stage, the injection molding process takes place, wherein the plastic mixture is melted and converted into a solid part. In the final stage, runner, gates, and any other unwanted plastic which is attached to the part, is removed and ground into appropriate granules [73]. In this study, we carried out the case study in an injection molding facility in Turkey.

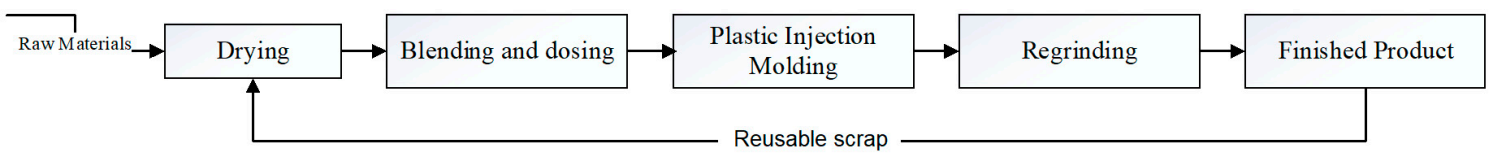

Figure 1. Stages of an injection molding process.

\subsection{The Calculation Process of the Proposed Model}

In this paper, we applied the BWM to obtain importance weights of the green criteria for supplier selection in injection molding. This method is based on comparison matrices as in AHP [29]. It requires less pairwise comparison data compared to AHP. In applying the proposed model, five experts evaluated the predefined green criteria. Expert 1 works as the manager of the facility and has 10 years of experience. Expert 2 is a five year experienced chemical engineer. He is also responsible for quality control of the facility. Expert 3 serves as a machine technician. The responsibility of the Expert 3 is to determine the raw material ratios and connect the molds to the machines. Expert 4 is a machine 
technician, too and has the same duties as Expert 3. Expert 5 works as a purchasing manager in the facility. He works in coordination with the company manager for the determination of appropriate suppliers. The first process in the proposed model is application of BWM to obtain weights of green supplier selection criteria. As an example, to the calculation of the main criteria with respect to Expert 1 , the following formulae is presented:

$$
\begin{aligned}
& \min \xi \\
& \text { st. } \\
& \mid \begin{array}{l}
\frac{w_{6}}{w_{1}}-4|\leq \xi,| \frac{w_{6}}{w_{2}}-7|\leq \xi,| \frac{w_{6}}{w_{3}}-1|\leq \xi,| \frac{w_{6}}{w_{4}}-2 \mid \leq \xi, \\
\frac{w_{6}}{w_{5}}-3|\leq \xi,| \frac{w_{6}}{w_{7}}-7|\leq \xi,| \frac{w_{6}}{w_{8}}-7 \mid \leq \xi \\
\frac{w_{1}}{w_{8}}-4|\leq \xi,| \frac{w_{2}}{w_{8}}-1|\leq \xi,| \frac{w_{3}}{w_{8}}-7|\leq \xi,| \frac{w_{4}}{w_{8}}-6 \mid \leq \xi, \\
\frac{w_{5}}{w_{8}}-5|\leq \xi, \xi,| \frac{w_{7}}{w_{8}}-1 \mid \leq \xi, \\
w_{1}+w_{2}+w_{3}+w_{4}+w_{5}+w_{6}+w_{7}+w_{8}=1 \\
w_{1}, w_{2}, w_{3}, w_{4}, w_{5}, w_{6}, w_{7}, w_{8} \geq 0
\end{array}
\end{aligned}
$$

Then, the BWM procedure is applied for each sub-criterion according to the five experts. Results of all calculations are presented in Table 3. The importance weights of green criteria are then used in evaluating suppliers by IT2F TOPSIS procedure. On the other hand, the calculated consistency ratios with respect to the experts are presented in Table 4. w1, w2, w3, w4, w5, w6, w7 and w8 are found as $0.100,0.035,0.205,0.170,0.135,0.285,0.035$ and 0.035 , respectively. We calculated the consistency ratios using $\xi$ and the corresponding consistency index in Table 2 by Equation (9).

$$
\text { Consistency ratio }=\frac{\xi}{\text { Consistency index }}
$$

Table 3. The local and global weights.

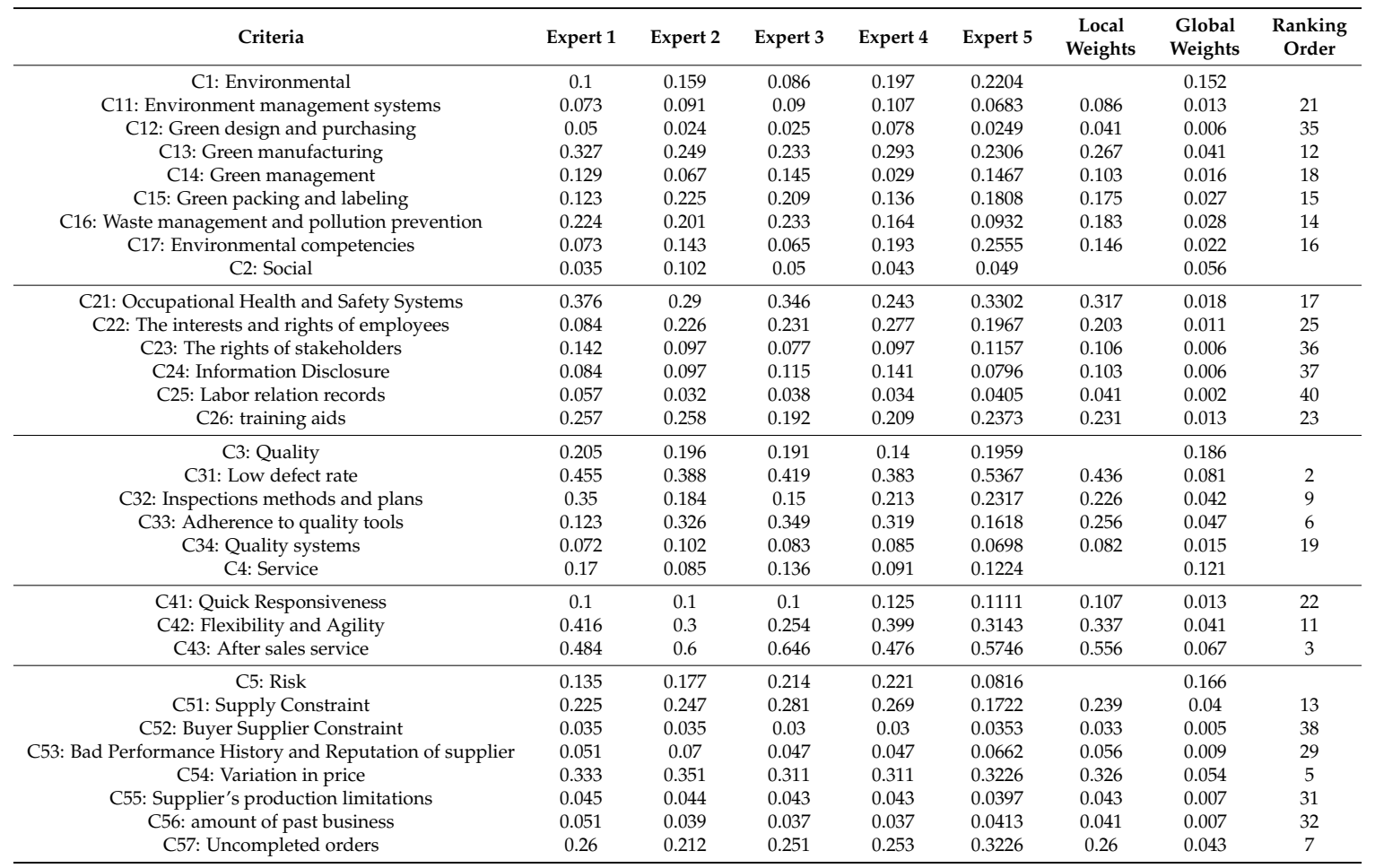


Table 3. Cont

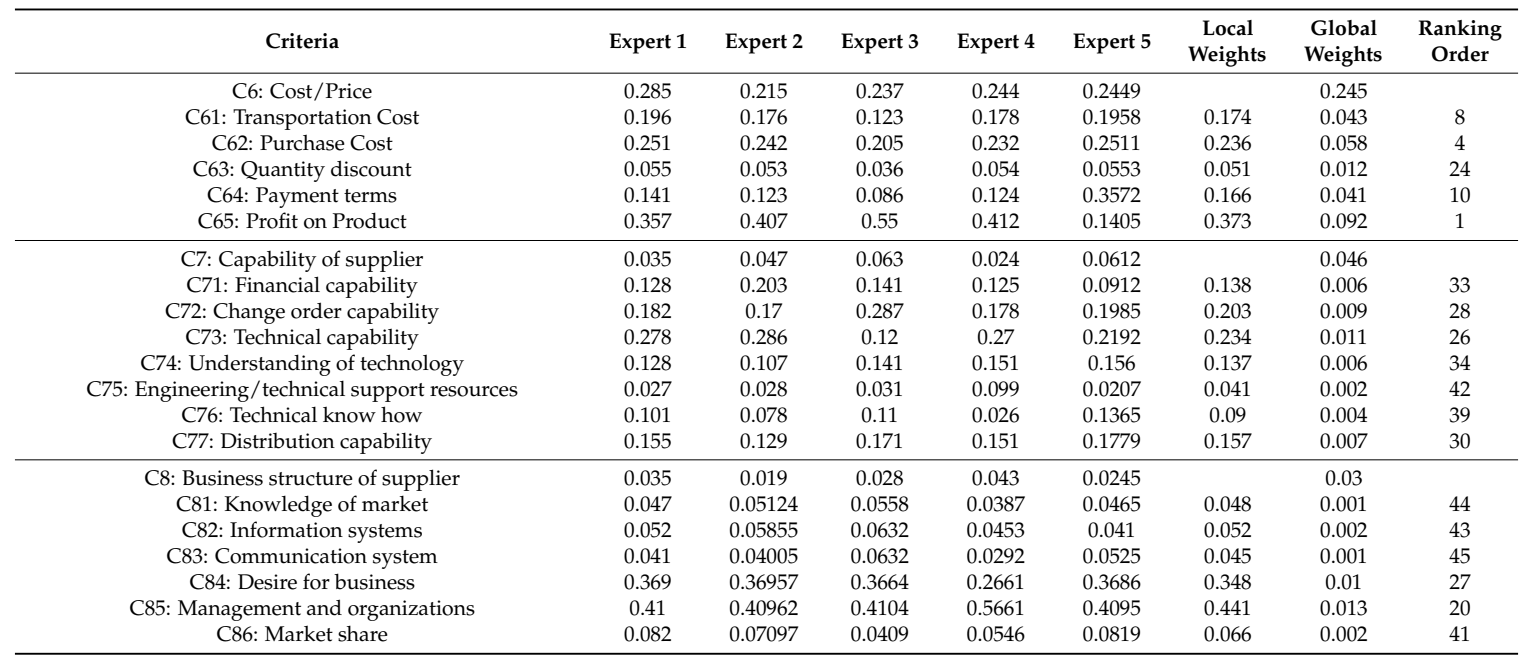

Table 4. The consistency for all experts.

\begin{tabular}{cccccc}
\hline Criteria & Expert 1 & Expert 2 & Expert 3 & Expert 4 & Expert 5 \\
\hline Main criteria & 0.3070 & 0.4721 & 0.2406 & 0.2406 & 0.1912 \\
Sub criteria of C1 & 0.1786 & 0.2275 & 0.3120 & 0.2406 & 0.2406 \\
Sub criteria of C2 & 0.1786 & 0.2237 & 0.2237 & 0.3072 & 0.3072 \\
Sub criteria of C3 & 0.0995 & 0.1181 & 0.0870 & 0.2174 & 0.1832 \\
Sub criteria of C4 & 0.0706 & 0.0000 & 0.1529 & 0.1181 & 0.1716 \\
Sub criteria of C5 & 0.1030 & 0.1912 & 0.2710 & 0.1912 & 0.2521 \\
Sub criteria of C6 & 0.1529 & 0.1832 & 0.2092 & 0.1832 & 0.1529 \\
Sub criteria of C7 & 0.2406 & 0.2528 & 0.2666 & 0.2406 & 0.3049 \\
Sub criteria of C8 & 0.1912 & 0.2348 & 0.1009 & 0.2155 & 0.1912 \\
\hline
\end{tabular}

For example, the consistency ratio for main criteria with respect to Expert 1 is calculated as $\xi / 3.73=0.307$ which implies a very good consistency.

The second process is concerned with IT2F TOPSIS application for suppliers. The suppliers are named as Supplier 1, Supplier 2 and Supplier 3. Supplier 1 is a local company. Compared to the other two companies, its production volume and transportation network is limited. Supplier 2 has a strong sales figure and its transportation network throughout the country is wide. This company makes production according to national and international quality standards. Supplier 3 is a global company. Technological levels are higher than the two other companies. Its number of defective products is relatively low, and its production volume is high. On the other hand, raw material prices are higher than the other two firms.

In this second process, the aggregated IT2F evaluation matrix for green supplier evaluation is obtained and it is shown in Table 5. Then, the weighted evaluation matrix is calculated multiplying the importance weights of green criteria and the aggregated IT2F evaluation matrix. The weighted evaluation matrix is presented in Table 6. Here, the importance weights of green criteria which are obtained from BWM are used as inputs of IT2F TOPSIS. Then, the ranking values for each green criterion with respect to three suppliers are calculated. The results are presented in Table 7. 
Table 5. The aggregated evaluation matrix.

\begin{tabular}{|c|c|c|c|}
\hline Criteria & Supplier 1 & Supplier 2 & Supplier 3 \\
\hline $\mathrm{C} 1$ & & & \\
\hline $\mathrm{C} 11$ & $((0.05 ; 0.2 ; 0.2 ; 0.4 ; 1 ; 1),(0.13 ; 0.2 ; 0.2 ; 0.3 ; 0.9 ; 0.9))$ & $((0.3 ; 0.5 ; 0.5 ; 0.7 ; 1 ; 1),(0.4 ; 0.5 ; 0.5 ; 0.6 ; 0.9 ; 0.9))$ & $((0.5 ; 0.7 ; 0.7 ; 0.85 ; 1 ; 1),(0.6 ; 0.7 ; 0.7 ; 0.78 ; 0.9 ; 0.9))$ \\
\hline $\mathrm{C} 12$ & $((0 ; 0.1 ; 0.1 ; 0.3 ; 1 ; 1),(0.05 ; 0.1 ; 0.1 ; 0.2 ; 0.9 ; 0.9))$ & $((0.3 ; 0.5 ; 0.5 ; 0.7 ; 1 ; 1),(0.4 ; 0.5 ; 0.5 ; 0.6 ; 0.9 ; 0.9))$ & $((0.3 ; 0.5 ; 0.5 ; 0.7 ; 1 ; 1),(0.4 ; 0.5 ; 0.5 ; 0.6 ; 0.9 ; 0.9))$ \\
\hline $\mathrm{C} 13$ & $((0.05 ; 0.2 ; 0.2 ; 0.4 ; 1 ; 1),(0.13 ; 0.2 ; 0.2 ; 0.3 ; 0.9 ; 0.9))$ & $((0.3 ; 0.5 ; 0.5 ; 0.7 ; 1 ; 1),(0.4 ; 0.5 ; 0.5 ; 0.6 ; 0.9 ; 0.9))$ & $((0.4 ; 0.6 ; 0.6 ; 0.75 ; 1 ; 1),(0.5 ; 0.6 ; 0.6 ; 0.68 ; 0.9 ; 0.9))$ \\
\hline $\mathrm{C} 14$ & $((0 ; 0.1 ; 0.1 ; 0.3 ; 1 ; 1),(0.05 ; 0.1 ; 0.1 ; 0.2 ; 0.9 ; 0.9))$ & $((0.1 ; 0.3 ; 0.3 ; 0.5 ; 1 ; 1),(0.2 ; 0.3 ; 0.3 ; 0.4 ; 0.9 ; 0.9))$ & $((0.1 ; 0.3 ; 0.3 ; 0.5 ; 1 ; 1),(0.2 ; 0.3 ; 0.3 ; 0.4 ; 0.9 ; 0.9))$ \\
\hline $\mathrm{C} 15$ & $((0.05 ; 0.2 ; 0.2 ; 0.4 ; 1 ; 1),(0.13 ; 0.2 ; 0.2 ; 0.3 ; 0.9 ; 0.9))$ & $((0.15 ; 0.3 ; 0.3 ; 0.5 ; 1 ; 1),(0.23 ; 0.3 ; 0.3 ; 0.4 ; 0.9 ; 0.9))$ & $((0.15 ; 0.3 ; 0.3 ; 0.5 ; 1 ; 1),(0.23 ; 0.3 ; 0.3 ; 0.4 ; 0.9 ; 0.9))$ \\
\hline C16 & $((0.2 ; 0.4 ; 0.4 ; 0.6 ; 1 ; 1),(0.3 ; 0.4 ; 0.4 ; 0.5 ; 0.9 ; 0.9))$ & $((0.5 ; 0.7 ; 0.7 ; 0.9 ; 1 ; 1),(0.6 ; 0.7 ; 0.7 ; 0.8 ; 0.9 ; 0.9))$ & $((0.6 ; 0.8 ; 0.8 ; 0.95 ; 1 ; 1),(0.7 ; 0.8 ; 0.8 ; 0.88 ; 0.9 ; 0.9))$ \\
\hline $\mathrm{C} 17$ & $((0.1 ; 0.3 ; 0.3 ; 0.5 ; 1 ; 1),(0.2 ; 0.3 ; 0.3 ; 0.4 ; 0.9 ; 0.9))$ & $((0.2 ; 0.4 ; 0.4 ; 0.6 ; 1 ; 1),(0.3 ; 0.4 ; 0.4 ; 0.5 ; 0.9 ; 0.9))$ & $((0.3 ; 0.5 ; 0.5 ; 0.7 ; 1 ; 1),(0.4 ; 0.5 ; 0.5 ; 0.6 ; 0.9 ; 0.9))$ \\
\hline $\mathrm{C} 2$ & $((0 ; 0 ; 0 ; 0 ; 0 ; 0),(0 ; 0 ; 0 ; 0 ; 0 ; 0))$ & $((0 ; 0 ; 0 ; 0 ; 0 ; 0),(0 ; 0 ; 0 ; 0 ; 0 ; 0))$ & $((0 ; 0 ; 0 ; 0 ; 0 ; 0),(0 ; 0 ; 0 ; 0 ; 0 ; 0))$ \\
\hline $\mathrm{C} 21$ & $((0.3 ; 0.5 ; 0.5 ; 0.7 ; 1 ; 1),(0.4 ; 0.5 ; 0.5 ; 0.6 ; 0.9 ; 0.9))$ & $((0.5 ; 0.7 ; 0.7 ; 0.9 ; 1 ; 1),(0.6 ; 0.7 ; 0.7 ; 0.8 ; 0.9 ; 0.9))$ & $((0.9 ; 1 ; 1 ; 1 ; 1 ; 1),(0.95 ; 1 ; 1 ; 1 ; 0.9 ; 0.9))$ \\
\hline $\mathrm{C} 22$ & $((0.05 ; 0.2 ; 0.2 ; 0.4 ; 1 ; 1),(0.13 ; 0.2 ; 0.2 ; 0.3 ; 0.9 ; 0.9))$ & $((0.1 ; 0.3 ; 0.3 ; 0.5 ; 1 ; 1),(0.2 ; 0.3 ; 0.3 ; 0.4 ; 0.9 ; 0.9))$ & $((0.2 ; 0.4 ; 0.4 ; 0.6 ; 1 ; 1),(0.3 ; 0.4 ; 0.4 ; 0.5 ; 0.9 ; 0.9))$ \\
\hline $\mathrm{C} 23$ & $((0.7 ; 0.85 ; 0.85 ; 0.95 ; 1 ; 1),(0.78 ; 0.85 ; 0.85 ; 0.9 ; 0.9 ; 0.9))$ & $((0.5 ; 0.7 ; 0.7 ; 0.85 ; 1 ; 1),(0.6 ; 0.7 ; 0.7 ; 0.78 ; 0.9 ; 0.9))$ & $((0.5 ; 0.7 ; 0.7 ; 0.9 ; 1 ; 1),(0.6 ; 0.7 ; 0.7 ; 0.8 ; 0.9 ; 0.9))$ \\
\hline $\mathrm{C} 24$ & $((0.05 ; 0.2 ; 0.2 ; 0.4 ; 1 ; 1),(0.13 ; 0.2 ; 0.2 ; 0.3 ; 0.9 ; 0.9))$ & $((0 ; 0.05 ; 0.05 ; 0.2 ; 1 ; 1),(0.03 ; 0.05 ; 0.05 ; 0.13 ; 0.9 ; 0.9))$ & $((0 ; 0.05 ; 0.05 ; 0.2 ; 1 ; 1),(0.03 ; 0.05 ; 0.05 ; 0.13 ; 0.9 ; 0.9))$ \\
\hline $\mathrm{C} 25$ & $((0.15 ; 0.3 ; 0.3 ; 0.5 ; 1 ; 1),(0.23 ; 0.3 ; 0.3 ; 0.4 ; 0.9 ; 0.9))$ & $((0.05 ; 0.2 ; 0.2 ; 0.4 ; 1 ; 1),(0.13 ; 0.2 ; 0.2 ; 0.3 ; 0.9 ; 0.9))$ & $((0.05 ; 0.2 ; 0.2 ; 0.4 ; 1 ; 1),(0.13 ; 0.2 ; 0.2 ; 0.3 ; 0.9 ; 0.9))$ \\
\hline $\mathrm{C} 26$ & $((0.15 ; 0.3 ; 0.3 ; 0.5 ; 1 ; 1),(0.23 ; 0.3 ; 0.3 ; 0.4 ; 0.9 ; 0.9))$ & $((0.9 ; 1 ; 1 ; 1 ; 1 ; 1),(0.95 ; 1 ; 1 ; 1 ; 0.9 ; 0.9))$ & $((0.8 ; 0.95 ; 0.95 ; 1 ; 1 ; 1),(0.88 ; 0.95 ; 0.95 ; 0.98 ; 0.9 ; 0.9))$ \\
\hline $\mathrm{C} 3$ & $((0 ; 0 ; 0 ; 0 ; 0 ; 0),(0 ; 0 ; 0 ; 0 ; 0 ; 0))$ & $((0 ; 0 ; 0 ; 0 ; 0 ; 0),(0 ; 0 ; 0 ; 0 ; 0 ; 0))$ & $((0 ; 0 ; 0 ; 0 ; 0 ; 0),(0 ; 0 ; 0 ; 0 ; 0 ; 0))$ \\
\hline C31 & $((0.2 ; 0.4 ; 0.4 ; 0.6 ; 1 ; 1),(0.3 ; 0.4 ; 0.4 ; 0.5 ; 0.9 ; 0.9))$ & $((0.4 ; 0.6 ; 0.6 ; 0.8 ; 1 ; 1),(0.5 ; 0.6 ; 0.6 ; 0.7 ; 0.9 ; 0.9))$ & $((0.7 ; 0.85 ; 0.85 ; 0.95 ; 1 ; 1),(0.78 ; 0.85 ; 0.85 ; 0.9 ; 0.9 ; 0.9))$ \\
\hline $\mathrm{C} 33$ & $((0.1 ; 0.3 ; 0.3 ; 0.5 ; 1 ; 1),(0.2 ; 0.3 ; 0.3 ; 0.4 ; 0.9 ; 0.9))$ & $((0.4 ; 0.6 ; 0.6 ; 0.8 ; 1 ; 1),(0.5 ; 0.6 ; 0.6 ; 0.7 ; 0.9 ; 0.9))$ & $((0.7 ; 0.85 ; 0.85 ; 0.95 ; 1 ; 1),(0.78 ; 0.85 ; 0.85 ; 0.9 ; 0.9 ; 0.9))$ \\
\hline $\mathrm{C} 34$ & $((0.3 ; 0.5 ; 0.5 ; 0.7 ; 1 ; 1),(0.4 ; 0.5 ; 0.5 ; 0.6 ; 0.9 ; 0.9))$ & $((0.5 ; 0.7 ; 0.7 ; 0.9 ; 1 ; 1),(0.6 ; 0.7 ; 0.7 ; 0.8 ; 0.9 ; 0.9))$ & $((0.6 ; 0.8 ; 0.8 ; 0.95 ; 1 ; 1),(0.7 ; 0.8 ; 0.8 ; 0.88 ; 0.9 ; 0.9))$ \\
\hline $\mathrm{C} 35$ & $((0.2 ; 0.4 ; 0.4 ; 0.6 ; 1 ; 1),(0.3 ; 0.4 ; 0.4 ; 0.5 ; 0.9 ; 0.9))$ & $((0.7 ; 0.85 ; 0.85 ; 0.95 ; 1 ; 1),(0.78 ; 0.85 ; 0.85 ; 0.9 ; 0.9 ; 0.9))$ & $((0.7 ; 0.85 ; 0.85 ; 0.95 ; 1 ; 1),(0.78 ; 0.85 ; 0.85 ; 0.9 ; 0.9 ; 0.9))$ \\
\hline $\mathrm{C} 4$ & $((0 ; 0 ; 0 ; 0 ; 0 ; 0),(0 ; 0 ; 0 ; 0 ; 0 ; 0))$ & $((0 ; 0 ; 0 ; 0 ; 0 ; 0),(0 ; 0 ; 0 ; 0 ; 0 ; 0))$ & $((0 ; 0 ; 0 ; 0 ; 0 ; 0),(0 ; 0 ; 0 ; 0 ; 0 ; 0))$ \\
\hline C41 & $((0.4 ; 0.6 ; 0.6 ; 0.8 ; 1 ; 1),(0.5 ; 0.6 ; 0.6 ; 0.7 ; 0.9 ; 0.9))$ & $((0.8 ; 0.95 ; 0.95 ; 1 ; 1 ; 1),(0.88 ; 0.95 ; 0.95 ; 0.98 ; 0.9 ; 0.9))$ & $((0.7 ; 0.9 ; 0.9 ; 1 ; 1 ; 1),(0.8 ; 0.9 ; 0.9 ; 0.95 ; 0.9 ; 0.9))$ \\
\hline $\mathrm{C} 42$ & $((0.3 ; 0.5 ; 0.5 ; 0.7 ; 1 ; 1),(0.4 ; 0.5 ; 0.5 ; 0.6 ; 0.9 ; 0.9))$ & $((0.5 ; 0.7 ; 0.7 ; 0.9 ; 1 ; 1),(0.6 ; 0.7 ; 0.7 ; 0.8 ; 0.9 ; 0.9))$ & $((0.6 ; 0.8 ; 0.8 ; 0.95 ; 1 ; 1),(0.7 ; 0.8 ; 0.8 ; 0.88 ; 0.9 ; 0.9))$ \\
\hline $\mathrm{C} 44$ & $((0.3 ; 0.5 ; 0.5 ; 0.7 ; 1 ; 1),(0.4 ; 0.5 ; 0.5 ; 0.6 ; 0.9 ; 0.9))$ & $((0.2 ; 0.4 ; 0.4 ; 0.6 ; 1 ; 1),(0.3 ; 0.4 ; 0.4 ; 0.5 ; 0.9 ; 0.9))$ & $((0.5 ; 0.7 ; 0.7 ; 0.9 ; 1 ; 1),(0.6 ; 0.7 ; 0.7 ; 0.8 ; 0.9 ; 0.9))$ \\
\hline $\mathrm{C} 5$ & $((0 ; 0 ; 0 ; 0 ; 0 ; 0),(0 ; 0 ; 0 ; 0 ; 0 ; 0))$ & $((0 ; 0 ; 0 ; 0 ; 0 ; 0),(0 ; 0 ; 0 ; 0 ; 0 ; 0))$ & $((0 ; 0 ; 0 ; 0 ; 0 ; 0),(0 ; 0 ; 0 ; 0 ; 0 ; 0))$ \\
\hline C51 & $((0.4 ; 0.6 ; 0.6 ; 0.8 ; 1 ; 1),(0.5 ; 0.6 ; 0.6 ; 0.7 ; 0.9 ; 0.9))$ & $((0.6 ; 0.8 ; 0.8 ; 0.95 ; 1 ; 1),(0.7 ; 0.8 ; 0.8 ; 0.88 ; 0.9 ; 0.9))$ & $((0.25 ; 0.4 ; 0.4 ; 0.6 ; 1 ; 1),(0.33 ; 0.4 ; 0.4 ; 0.5 ; 0.9 ; 0.9))$ \\
\hline C52 & $((0.2 ; 0.4 ; 0.4 ; 0.6 ; 1 ; 1),(0.3 ; 0.4 ; 0.4 ; 0.5 ; 0.9 ; 0.9))$ & $((0 ; 0.05 ; 0.05 ; 0.2 ; 1 ; 1),(0.03 ; 0.05 ; 0.05 ; 0.13 ; 0.9 ; 0.9))$ & $((0.15 ; 0.3 ; 0.3 ; 0.5 ; 1 ; 1),(0.23 ; 0.3 ; 0.3 ; 0.4 ; 0.9 ; 0.9))$ \\
\hline $\mathrm{C} 54$ & $((0.3 ; 0.5 ; 0.5 ; 0.7 ; 1 ; 1),(0.4 ; 0.5 ; 0.5 ; 0.6 ; 0.9 ; 0.9))$ & $((0.05 ; 0.2 ; 0.2 ; 0.4 ; 1 ; 1),(0.13 ; 0.2 ; 0.2 ; 0.3 ; 0.9 ; 0.9))$ & $((0 ; 0.05 ; 0.05 ; 0.2 ; 1 ; 1),(0.03 ; 0.05 ; 0.05 ; 0.13 ; 0.9 ; 0.9))$ \\
\hline C56 & $((0.3 ; 0.5 ; 0.5 ; 0.7 ; 1 ; 1),(0.4 ; 0.5 ; 0.5 ; 0.6 ; 0.9 ; 0.9))$ & $((0.15 ; 0.3 ; 0.3 ; 0.5 ; 1 ; 1),(0.23 ; 0.3 ; 0.3 ; 0.4 ; 0.9 ; 0.9))$ & $((0.05 ; 0.2 ; 0.2 ; 0.4 ; 1 ; 1),(0.13 ; 0.2 ; 0.2 ; 0.3 ; 0.9 ; 0.9))$ \\
\hline C57 & $((0.2 ; 0.4 ; 0.4 ; 0.6 ; 1 ; 1),(0.3 ; 0.4 ; 0.4 ; 0.5 ; 0.9 ; 0.9))$ & $((0.05 ; 0.15 ; 0.15 ; 0.3 ; 1 ; 1),(0.1 ; 0.15 ; 0.15 ; 0.23 ; 0.9 ; 0.9))$ & $((0.15 ; 0.3 ; 0.3 ; 0.5 ; 1 ; 1),(0.23 ; 0.3 ; 0.3 ; 0.4 ; 0.9 ; 0.9))$ \\
\hline C58 & $((0.4 ; 0.6 ; 0.6 ; 0.8 ; 1 ; 1),(0.5 ; 0.6 ; 0.6 ; 0.7 ; 0.9 ; 0.9))$ & $((0.8 ; 0.95 ; 0.95 ; 1 ; 1 ; 1),(0.88 ; 0.95 ; 0.95 ; 0.98 ; 0.9 ; 0.9))$ & $((0.8 ; 0.95 ; 0.95 ; 1 ; 1 ; 1),(0.88 ; 0.95 ; 0.95 ; 0.98 ; 0.9 ; 0.9))$ \\
\hline C59 & $((0.2 ; 0.4 ; 0.4 ; 0.6 ; 1 ; 1),(0.3 ; 0.4 ; 0.4 ; 0.5 ; 0.9 ; 0.9))$ & $((0 ; 0.05 ; 0.05 ; 0.2 ; 1 ; 1),(0.03 ; 0.05 ; 0.05 ; 0.13 ; 0.9 ; 0.9))$ & $((0 ; 0.05 ; 0.05 ; 0.2 ; 1 ; 1),(0.03 ; 0.05 ; 0.05 ; 0.13 ; 0.9 ; 0.9))$ \\
\hline C6 & $((0 ; 0 ; 0 ; 0 ; 0 ; 0),(0 ; 0 ; 0 ; 0 ; 0 ; 0))$ & $((0 ; 0 ; 0 ; 0 ; 0 ; 0),(0 ; 0 ; 0 ; 0 ; 0 ; 0))$ & $((0 ; 0 ; 0 ; 0 ; 0 ; 0),(0 ; 0 ; 0 ; 0 ; 0 ; 0))$ \\
\hline C61 & $((0.05 ; 0.2 ; 0.2 ; 0.4 ; 1 ; 1),(0.13 ; 0.2 ; 0.2 ; 0.3 ; 0.9 ; 0.9))$ & $((0.15 ; 0.3 ; 0.3 ; 0.5 ; 1 ; 1),(0.23 ; 0.3 ; 0.3 ; 0.4 ; 0.9 ; 0.9))$ & $((0.2 ; 0.4 ; 0.4 ; 0.6 ; 1 ; 1),(0.3 ; 0.4 ; 0.4 ; 0.5 ; 0.9 ; 0.9))$ \\
\hline
\end{tabular}


Table 5. Cont.

\begin{tabular}{|c|c|c|c|}
\hline Criteria & Supplier 1 & Supplier 2 & Supplier 3 \\
\hline $\mathrm{C} 62$ & $((0.3 ; 0.5 ; 0.5 ; 0.7 ; 1 ; 1),(0.4 ; 0.5 ; 0.5 ; 0.6 ; 0.9 ; 0.9))$ & $((0.5 ; 0.7 ; 0.7 ; 0.85 ; 1 ; 1),(0.6 ; 0.7 ; 0.7 ; 0.78 ; 0.9 ; 0.9))$ & $((0.6 ; 0.8 ; 0.8 ; 0.95 ; 1 ; 1),(0.7 ; 0.8 ; 0.8 ; 0.88 ; 0.9 ; 0.9))$ \\
\hline C63 & $((0.15 ; 0.3 ; 0.3 ; 0.5 ; 1 ; 1),(0.23 ; 0.3 ; 0.3 ; 0.4 ; 0.9 ; 0.9))$ & $((0.2 ; 0.4 ; 0.4 ; 0.6 ; 1 ; 1),(0.3 ; 0.4 ; 0.4 ; 0.5 ; 0.9 ; 0.9))$ & $((0.3 ; 0.5 ; 0.5 ; 0.7 ; 1 ; 1),(0.4 ; 0.5 ; 0.5 ; 0.6 ; 0.9 ; 0.9))$ \\
\hline C64 & $((0.6 ; 0.8 ; 0.8 ; 0.95 ; 1 ; 1),(0.7 ; 0.8 ; 0.8 ; 0.88 ; 0.9 ; 0.9))$ & $((0.4 ; 0.6 ; 0.6 ; 0.8 ; 1 ; 1),(0.5 ; 0.6 ; 0.6 ; 0.7 ; 0.9 ; 0.9))$ & $((0.2 ; 0.4 ; 0.4 ; 0.6 ; 1 ; 1),(0.3 ; 0.4 ; 0.4 ; 0.5 ; 0.9 ; 0.9))$ \\
\hline C65 & $((0.4 ; 0.6 ; 0.6 ; 0.8 ; 1 ; 1),(0.5 ; 0.6 ; 0.6 ; 0.7 ; 0.9 ; 0.9))$ & $((0.1 ; 0.3 ; 0.3 ; 0.5 ; 1 ; 1),(0.2 ; 0.3 ; 0.3 ; 0.4 ; 0.9 ; 0.9))$ & $((0.2 ; 0.4 ; 0.4 ; 0.6 ; 1 ; 1),(0.3 ; 0.4 ; 0.4 ; 0.5 ; 0.9 ; 0.9))$ \\
\hline $\mathrm{C} 7$ & $((0 ; 0 ; 0 ; 0 ; 0 ; 0),(0 ; 0 ; 0 ; 0 ; 0 ; 0))$ & $((0 ; 0 ; 0 ; 0 ; 0 ; 0),(0 ; 0 ; 0 ; 0 ; 0 ; 0))$ & $((0 ; 0 ; 0 ; 0 ; 0 ; 0),(0 ; 0 ; 0 ; 0 ; 0 ; 0))$ \\
\hline C71 & $((0.2 ; 0.4 ; 0.4 ; 0.6 ; 1 ; 1),(0.3 ; 0.4 ; 0.4 ; 0.5 ; 0.9 ; 0.9))$ & $((0.4 ; 0.6 ; 0.6 ; 0.8 ; 1 ; 1),(0.5 ; 0.6 ; 0.6 ; 0.7 ; 0.9 ; 0.9))$ & $((0.5 ; 0.7 ; 0.7 ; 0.9 ; 1 ; 1),(0.6 ; 0.7 ; 0.7 ; 0.8 ; 0.9 ; 0.9))$ \\
\hline $\mathrm{C} 72$ & $((0.5 ; 0.7 ; 0.7 ; 0.9 ; 1 ; 1),(0.6 ; 0.7 ; 0.7 ; 0.8 ; 0.9 ; 0.9))$ & $((0.4 ; 0.6 ; 0.6 ; 0.8 ; 1 ; 1),(0.5 ; 0.6 ; 0.6 ; 0.7 ; 0.9 ; 0.9))$ & $((0.3 ; 0.5 ; 0.5 ; 0.7 ; 1 ; 1),(0.4 ; 0.5 ; 0.5 ; 0.6 ; 0.9 ; 0.9))$ \\
\hline C73 & $((0.1 ; 0.3 ; 0.3 ; 0.5 ; 1 ; 1),(0.2 ; 0.3 ; 0.3 ; 0.4 ; 0.9 ; 0.9))$ & $((0.4 ; 0.6 ; 0.6 ; 0.8 ; 1 ; 1),(0.5 ; 0.6 ; 0.6 ; 0.7 ; 0.9 ; 0.9))$ & $((0.7 ; 0.85 ; 0.85 ; 0.95 ; 1 ; 1),(0.78 ; 0.85 ; 0.85 ; 0.9 ; 0.9 ; 0.9))$ \\
\hline C74 & $((0.2 ; 0.4 ; 0.4 ; 0.6 ; 1 ; 1),(0.3 ; 0.4 ; 0.4 ; 0.5 ; 0.9 ; 0.9))$ & $((0.5 ; 0.7 ; 0.7 ; 0.9 ; 1 ; 1),(0.6 ; 0.7 ; 0.7 ; 0.8 ; 0.9 ; 0.9))$ & $((0.6 ; 0.8 ; 0.8 ; 0.95 ; 1 ; 1),(0.7 ; 0.8 ; 0.8 ; 0.88 ; 0.9 ; 0.9))$ \\
\hline C75 & $((0.2 ; 0.4 ; 0.4 ; 0.6 ; 1 ; 1),(0.3 ; 0.4 ; 0.4 ; 0.5 ; 0.9 ; 0.9))$ & $((0.7 ; 0.85 ; 0.85 ; 0.95 ; 1 ; 1),(0.78 ; 0.85 ; 0.85 ; 0.9 ; 0.9 ; 0.9))$ & $((0.7 ; 0.9 ; 0.9 ; 1 ; 1 ; 1),(0.8 ; 0.9 ; 0.9 ; 0.95 ; 0.9 ; 0.9))$ \\
\hline C76 & $((0.2 ; 0.4 ; 0.4 ; 0.6 ; 1 ; 1),(0.3 ; 0.4 ; 0.4 ; 0.5 ; 0.9 ; 0.9))$ & $((0.9 ; 1 ; 1 ; 1 ; 1 ; 1),(0.95 ; 1 ; 1 ; 1 ; 0.9 ; 0.9))$ & $((0.8 ; 0.95 ; 0.95 ; 1 ; 1 ; 1),(0.88 ; 0.95 ; 0.95 ; 0.98 ; 0.9 ; 0.9))$ \\
\hline $\mathrm{C} 77$ & $((0.2 ; 0.4 ; 0.4 ; 0.6 ; 1 ; 1),(0.3 ; 0.4 ; 0.4 ; 0.5 ; 0.9 ; 0.9))$ & $((0.5 ; 0.7 ; 0.7 ; 0.9 ; 1 ; 1),(0.6 ; 0.7 ; 0.7 ; 0.8 ; 0.9 ; 0.9))$ & $((0.4 ; 0.6 ; 0.6 ; 0.8 ; 1 ; 1),(0.5 ; 0.6 ; 0.6 ; 0.7 ; 0.9 ; 0.9))$ \\
\hline $\mathrm{C} 8$ & $((0 ; 0 ; 0 ; 0 ; 0 ; 0),(0 ; 0 ; 0 ; 0 ; 0 ; 0))$ & $((0 ; 0 ; 0 ; 0 ; 0 ; 0),(0 ; 0 ; 0 ; 0 ; 0 ; 0))$ & $((0 ; 0 ; 0 ; 0 ; 0 ; 0),(0 ; 0 ; 0 ; 0 ; 0 ; 0))$ \\
\hline $\mathrm{C} 81$ & $((0.6 ; 0.75 ; 0.75 ; 0.85 ; 1 ; 1),(0.68 ; 0.75 ; 0.75 ; 0.8 ; 0.9 ; 0.9))$ & $((0.6 ; 0.8 ; 0.8 ; 0.95 ; 1 ; 1),(0.7 ; 0.8 ; 0.8 ; 0.88 ; 0.9 ; 0.9))$ & $((0.6 ; 0.8 ; 0.8 ; 0.95 ; 1 ; 1),(0.7 ; 0.8 ; 0.8 ; 0.88 ; 0.9 ; 0.9))$ \\
\hline $\mathrm{C} 82$ & $((0 ; 0.05 ; 0.05 ; 0.2 ; 1 ; 1),(0.03 ; 0.05 ; 0.05 ; 0.13 ; 0.9 ; 0.9))$ & $((0 ; 0.1 ; 0.1 ; 0.3 ; 1 ; 1),(0.05 ; 0.1 ; 0.1 ; 0.2 ; 0.9 ; 0.9))$ & $((0.05 ; 0.2 ; 0.2 ; 0.4 ; 1 ; 1),(0.13 ; 0.2 ; 0.2 ; 0.3 ; 0.9 ; 0.9))$ \\
\hline $\mathrm{C} 83$ & $((0.2 ; 0.4 ; 0.4 ; 0.6 ; 1 ; 1),(0.3 ; 0.4 ; 0.4 ; 0.5 ; 0.9 ; 0.9))$ & $((0.1 ; 0.3 ; 0.3 ; 0.5 ; 1 ; 1),(0.2 ; 0.3 ; 0.3 ; 0.4 ; 0.9 ; 0.9))$ & $((0.2 ; 0.4 ; 0.4 ; 0.6 ; 1 ; 1),(0.3 ; 0.4 ; 0.4 ; 0.5 ; 0.9 ; 0.9))$ \\
\hline $\mathrm{C} 84$ & $((0.7 ; 0.85 ; 0.85 ; 0.95 ; 1 ; 1),(0.78 ; 0.85 ; 0.85 ; 0.9 ; 0.9 ; 0.9))$ & $((0.4 ; 0.6 ; 0.6 ; 0.8 ; 1 ; 1),(0.5 ; 0.6 ; 0.6 ; 0.7 ; 0.9 ; 0.9))$ & $((0.2 ; 0.4 ; 0.4 ; 0.6 ; 1 ; 1),(0.3 ; 0.4 ; 0.4 ; 0.5 ; 0.9 ; 0.9))$ \\
\hline $\mathrm{C} 85$ & $((0.05 ; 0.2 ; 0.2 ; 0.4 ; 1 ; 1),(0.13 ; 0.2 ; 0.2 ; 0.3 ; 0.9 ; 0.9))$ & $((0.2 ; 0.4 ; 0.4 ; 0.6 ; 1 ; 1),(0.3 ; 0.4 ; 0.4 ; 0.5 ; 0.9 ; 0.9))$ & $((0.3 ; 0.5 ; 0.5 ; 0.7 ; 1 ; 1),(0.4 ; 0.5 ; 0.5 ; 0.6 ; 0.9 ; 0.9))$ \\
\hline $\mathrm{C} 86$ & $((0.4 ; 0.6 ; 0.6 ; 0.8 ; 1 ; 1),(0.5 ; 0.6 ; 0.6 ; 0.7 ; 0.9 ; 0.9))$ & $((0.2 ; 0.4 ; 0.4 ; 0.6 ; 1 ; 1),(0.3 ; 0.4 ; 0.4 ; 0.5 ; 0.9 ; 0.9))$ & $((0.2 ; 0.4 ; 0.4 ; 0.6 ; 1 ; 1),(0.3 ; 0.4 ; 0.4 ; 0.5 ; 0.9 ; 0.9))$ \\
\hline
\end{tabular}


Table 6. The weighted evaluation matrix.

\begin{tabular}{|c|c|c|c|}
\hline Criteria & Supplier 1 & Supplier 2 & Supplier 3 \\
\hline \multicolumn{4}{|l|}{$\mathrm{C} 1$} \\
\hline $\mathrm{C} 11$ & $((0 ; 0 ; 0 ; 0.01 ; 1 ; 1),(0 ; 0 ; 0 ; 0 ; 0.9 ; 0.9))$ & $((0 ; 0.01 ; 0.01 ; 0.01 ; 1 ; 1),(0.01 ; 0.01 ; 0.01 ; 0.01 ; 0.9 ; 0.9))$ & $((0.01 ; 0.01 ; 0.01 ; 0.01 ; 1 ; 1),(0.01 ; 0.01 ; 0.01 ; 0.01 ; 0.9 ; 0.9))$ \\
\hline $\mathrm{C} 12$ & $((0 ; 0 ; 0 ; 0 ; 1 ; 1),(0 ; 0 ; 0 ; 0 ; 0.9 ; 0.9))$ & $((0 ; 0 ; 0 ; 0 ; 1 ; 1),(0 ; 0 ; 0 ; 0 ; 0.9 ; 0.9))$ & $((0 ; 0 ; 0 ; 0 ; 1 ; 1),(0 ; 0 ; 0 ; 0 ; 0.9 ; 0.9))$ \\
\hline $\mathrm{C} 13$ & $((0 ; 0.01 ; 0.01 ; 0.02 ; 1 ; 1),(0.01 ; 0.01 ; 0.01 ; 0.01 ; 0.9 ; 0.9))$ & $((0.01 ; 0.02 ; 0.02 ; 0.03 ; 1 ; 1),(0.02 ; 0.02 ; 0.02 ; 0.02 ; 0.9 ; 0.9))$ & $((0.02 ; 0.02 ; 0.02 ; 0.03 ; 1 ; 1),(0.02 ; 0.02 ; 0.02 ; 0.03 ; 0.9 ; 0.9))$ \\
\hline $\mathrm{C} 14$ & $((0 ; 0 ; 0 ; 0 ; 1 ; 1),(0 ; 0 ; 0 ; 0 ; 0.9 ; 0.9))$ & $((0 ; 0 ; 0 ; 0.01 ; 1 ; 1),(0 ; 0 ; 0 ; 0.01 ; 0.9 ; 0.9))$ & $((0 ; 0 ; 0 ; 0.01 ; 1 ; 1),(0 ; 0 ; 0 ; 0.01 ; 0.9 ; 0.9))$ \\
\hline C15 & $((0 ; 0.01 ; 0.01 ; 0.01 ; 1 ; 1),(0 ; 0.01 ; 0.01 ; 0.01 ; 0.9 ; 0.9))$ & $((0 ; 0.01 ; 0.01 ; 0.01 ; 1 ; 1),(0.01 ; 0.01 ; 0.01 ; 0.01 ; 0.9 ; 0.9))$ & $((0 ; 0.01 ; 0.01 ; 0.01 ; 1 ; 1),(0.01 ; 0.01 ; 0.01 ; 0.01 ; 0.9 ; 0.9))$ \\
\hline $\mathrm{C} 16$ & $((0.01 ; 0.01 ; 0.01 ; 0.02 ; 1 ; 1),(0.01 ; 0.01 ; 0.01 ; 0.01 ; 0.9 ; 0.9))$ & $((0.01 ; 0.02 ; 0.02 ; 0.03 ; 1 ; 1),(0.02 ; 0.02 ; 0.02 ; 0.02 ; 0.9 ; 0.9))$ & $((0.02 ; 0.02 ; 0.02 ; 0.03 ; 1 ; 1),(0.02 ; 0.02 ; 0.02 ; 0.02 ; 0.9 ; 0.9))$ \\
\hline $\mathrm{C} 17$ & $((0 ; 0.01 ; 0.01 ; 0.01 ; 1 ; 1),(0 ; 0.01 ; 0.01 ; 0.01 ; 0.9 ; 0.9))$ & $((0 ; 0.01 ; 0.01 ; 0.01 ; 1 ; 1),(0.01 ; 0.01 ; 0.01 ; 0.01 ; 0.9 ; 0.9))$ & $((0.01 ; 0.01 ; 0.01 ; 0.02 ; 1 ; 1),(0.01 ; 0.01 ; 0.01 ; 0.01 ; 0.9 ; 0.9))$ \\
\hline \multicolumn{4}{|l|}{$\mathrm{C} 2$} \\
\hline $\mathrm{C} 21$ & $((0.01 ; 0.01 ; 0.01 ; 0.01 ; 1 ; 1),(0.01 ; 0.01 ; 0.01 ; 0.01 ; 0.9 ; 0.9))$ & $((0.01 ; 0.01 ; 0.01 ; 0.02 ; 1 ; 1),(0.01 ; 0.01 ; 0.01 ; 0.01 ; 0.9 ; 0.9))$ & $((0.02 ; 0.02 ; 0.02 ; 0.02 ; 1 ; 1),(0.02 ; 0.02 ; 0.02 ; 0.02 ; 0.9 ; 0.9))$ \\
\hline $\mathrm{C} 22$ & $((0 ; 0 ; 0 ; 0 ; 1 ; 1),(0 ; 0 ; 0 ; 0 ; 0.9 ; 0.9))$ & $((0 ; 0 ; 0 ; 0.01 ; 1 ; 1),(0 ; 0 ; 0 ; 0 ; 0.9 ; 0.9))$ & $((0 ; 0 ; 0 ; 0.01 ; 1 ; 1),(0 ; 0 ; 0 ; 0.01 ; 0.9 ; 0.9))$ \\
\hline $\mathrm{C} 23$ & $((0 ; 0.01 ; 0.01 ; 0.01 ; 1 ; 1),(0 ; 0.01 ; 0.01 ; 0.01 ; 0.9 ; 0.9))$ & $((0 ; 0 ; 0 ; 0.01 ; 1 ; 1),(0 ; 0 ; 0 ; 0 ; 0.9 ; 0.9))$ & $((0 ; 0 ; 0 ; 0.01 ; 1 ; 1),(0 ; 0 ; 0 ; 0 ; 0.9 ; 0.9))$ \\
\hline $\mathrm{C} 24$ & $((0 ; 0 ; 0 ; 0 ; 1 ; 1),(0 ; 0 ; 0 ; 0 ; 0.9 ; 0.9))$ & $((0 ; 0 ; 0 ; 0 ; 1 ; 1),(0 ; 0 ; 0 ; 0 ; 0.9 ; 0.9))$ & $((0 ; 0 ; 0 ; 0 ; 1 ; 1),(0 ; 0 ; 0 ; 0 ; 0.9 ; 0.9))$ \\
\hline $\mathrm{C} 25$ & $((0 ; 0 ; 0 ; 0 ; 1 ; 1),(0 ; 0 ; 0 ; 0 ; 0.9 ; 0.9))$ & $((0 ; 0 ; 0 ; 0 ; 1 ; 1),(0 ; 0 ; 0 ; 0 ; 0.9 ; 0.9))$ & $((0 ; 0 ; 0 ; 0 ; 1 ; 1),(0 ; 0 ; 0 ; 0 ; 0.9 ; 0.9))$ \\
\hline $\mathrm{C} 26$ & $((0 ; 0 ; 0 ; 0.01 ; 1 ; 1),(0 ; 0 ; 0 ; 0.01 ; 0.9 ; 0.9))$ & $((0.01 ; 0.01 ; 0.01 ; 0.01 ; 1 ; 1),(0.01 ; 0.01 ; 0.01 ; 0.01 ; 0.9 ; 0.9))$ & $((0.01 ; 0.01 ; 0.01 ; 0.01 ; 1 ; 1),(0.01 ; 0.01 ; 0.01 ; 0.01 ; 0.9 ; 0.9))$ \\
\hline \multicolumn{4}{|c|}{ ) } \\
\hline C31 & $((0.02 ; 0.03 ; 0.03 ; 0.05 ; 1 ; 1),(0.02 ; 0.03 ; 0.03 ; 0.04 ; 0.9 ; 0.9))$ & $((0.03 ; 0.05 ; 0.05 ; 0.06 ; 1 ; 1),(0.04 ; 0.05 ; 0.05 ; 0.06 ; 0.9 ; 0.9))$ & $((0.06 ; 0.07 ; 0.07 ; 0.08 ; 1 ; 1),(0.06 ; 0.07 ; 0.07 ; 0.07 ; 0.9 ; 0.9))$ \\
\hline $\mathrm{C} 33$ & $((0 ; 0.01 ; 0.01 ; 0.02 ; 1 ; 1),(0.01 ; 0.01 ; 0.01 ; 0.02 ; 0.9 ; 0.9))$ & $((0.02 ; 0.03 ; 0.03 ; 0.03 ; 1 ; 1),(0.02 ; 0.03 ; 0.03 ; 0.03 ; 0.9 ; 0.9))$ & $((0.03 ; 0.04 ; 0.04 ; 0.04 ; 1 ; 1),(0.03 ; 0.04 ; 0.04 ; 0.04 ; 0.9 ; 0.9))$ \\
\hline C34 & $((0.01 ; 0.02 ; 0.02 ; 0.03 ; 1 ; 1),(0.02 ; 0.02 ; 0.02 ; 0.03 ; 0.9 ; 0.9))$ & $((0.02 ; 0.03 ; 0.03 ; 0.04 ; 1 ; 1),(0.03 ; 0.03 ; 0.03 ; 0.04 ; 0.9 ; 0.9))$ & $((0.03 ; 0.04 ; 0.04 ; 0.05 ; 1 ; 1),(0.03 ; 0.04 ; 0.04 ; 0.04 ; 0.9 ; 0.9))$ \\
\hline C35 & $((0 ; 0.01 ; 0.01 ; 0.01 ; 1 ; 1),(0 ; 0.01 ; 0.01 ; 0.01 ; 0.9 ; 0.9))$ & $((0.01 ; 0.01 ; 0.01 ; 0.01 ; 1 ; 1),(0.01 ; 0.01 ; 0.01 ; 0.01 ; 0.9 ; 0.9))$ & $((0.01 ; 0.01 ; 0.01 ; 0.01 ; 1 ; 1),(0.01 ; 0.01 ; 0.01 ; 0.01 ; 0.9 ; 0.9))$ \\
\hline \multicolumn{4}{|c|}{ ") } \\
\hline $\mathrm{C} 41$ & $((0.01 ; 0.01 ; 0.01 ; 0.01 ; 1 ; 1),(0.01 ; 0.01 ; 0.01 ; 0.01 ; 0.9 ; 0.9))$ & $((0.01 ; 0.01 ; 0.01 ; 0.01 ; 1 ; 1),(0.01 ; 0.01 ; 0.01 ; 0.01 ; 0.9 ; 0.9))$ & $((0.01 ; 0.01 ; 0.01 ; 0.01 ; 1 ; 1),(0.01 ; 0.01 ; 0.01 ; 0.01 ; 0.9 ; 0.9))$ \\
\hline $\mathrm{C} 42$ & $((0.01 ; 0.02 ; 0.02 ; 0.03 ; 1 ; 1),(0.02 ; 0.02 ; 0.02 ; 0.02 ; 0.9 ; 0.9))$ & $((0.02 ; 0.03 ; 0.03 ; 0.04 ; 1 ; 1),(0.02 ; 0.03 ; 0.03 ; 0.03 ; 0.9 ; 0.9))$ & $((0.02 ; 0.03 ; 0.03 ; 0.04 ; 1 ; 1),(0.03 ; 0.03 ; 0.03 ; 0.04 ; 0.9 ; 0.9))$ \\
\hline C44 & $((0.02 ; 0.03 ; 0.03 ; 0.05 ; 1 ; 1),(0.03 ; 0.03 ; 0.03 ; 0.04 ; 0.9 ; 0.9))$ & $((0.01 ; 0.03 ; 0.03 ; 0.04 ; 1 ; 1),(0.02 ; 0.03 ; 0.03 ; 0.03 ; 0.9 ; 0.9))$ & $((0.03 ; 0.05 ; 0.05 ; 0.06 ; 1 ; 1),(0.04 ; 0.05 ; 0.05 ; 0.05 ; 0.9 ; 0.9))$ \\
\hline \multicolumn{4}{|l|}{ C5 } \\
\hline C51 & $((0.02 ; 0.02 ; 0.02 ; 0.03 ; 1 ; 1),(0.02 ; 0.02 ; 0.02 ; 0.03 ; 0.9 ; 0.9))$ & $((0.02 ; 0.03 ; 0.03 ; 0.04 ; 1 ; 1),(0.03 ; 0.03 ; 0.03 ; 0.03 ; 0.9 ; 0.9))$ & $((0.01 ; 0.02 ; 0.02 ; 0.02 ; 1 ; 1),(0.01 ; 0.02 ; 0.02 ; 0.02 ; 0.9 ; 0.9))$ \\
\hline C52 & $((0 ; 0 ; 0 ; 0 ; 1 ; 1),(0 ; 0 ; 0 ; 0 ; 0.9 ; 0.9))$ & $((0 ; 0 ; 0 ; 0 ; 1 ; 1),(0 ; 0 ; 0 ; 0 ; 0.9 ; 0.9))$ & $((0 ; 0 ; 0 ; 0 ; 1 ; 1),(0 ; 0 ; 0 ; 0 ; 0.9 ; 0.9))$ \\
\hline $\mathrm{C} 54$ & $((0 ; 0 ; 0 ; 0.01 ; 1 ; 1),(0 ; 0 ; 0 ; 0.01 ; 0.9 ; 0.9))$ & $((0 ; 0 ; 0 ; 0 ; 1 ; 1),(0 ; 0 ; 0 ; 0 ; 0.9 ; 0.9))$ & $((0 ; 0 ; 0 ; 0 ; 1 ; 1),(0 ; 0 ; 0 ; 0 ; 0.9 ; 0.9))$ \\
\hline C56 & $((0.02 ; 0.03 ; 0.03 ; 0.04 ; 1 ; 1),(0.02 ; 0.03 ; 0.03 ; 0.03 ; 0.9 ; 0.9))$ & $((0.01 ; 0.02 ; 0.02 ; 0.03 ; 1 ; 1),(0.01 ; 0.02 ; 0.02 ; 0.02 ; 0.9 ; 0.9))$ & $((0 ; 0.01 ; 0.01 ; 0.02 ; 1 ; 1),(0.01 ; 0.01 ; 0.01 ; 0.02 ; 0.9 ; 0.9))$ \\
\hline C57 & $((0 ; 0 ; 0 ; 0 ; 1 ; 1),(0 ; 0 ; 0 ; 0 ; 0.9 ; 0.9))$ & $((0 ; 0 ; 0 ; 0 ; 1 ; 1),(0 ; 0 ; 0 ; 0 ; 0.9 ; 0.9))$ & $((0 ; 0 ; 0 ; 0 ; 1 ; 1),(0 ; 0 ; 0 ; 0 ; 0.9 ; 0.9))$ \\
\hline C58 & $((0 ; 0 ; 0 ; 0.01 ; 1 ; 1),(0 ; 0 ; 0 ; 0 ; 0.9 ; 0.9))$ & $((0.01 ; 0.01 ; 0.01 ; 0.01 ; 1 ; 1),(0.01 ; 0.01 ; 0.01 ; 0.01 ; 0.9 ; 0.9))$ & $((0.01 ; 0.01 ; 0.01 ; 0.01 ; 1 ; 1),(0.01 ; 0.01 ; 0.01 ; 0.01 ; 0.9 ; 0.9))$ \\
\hline C59 & $((0.01 ; 0.02 ; 0.02 ; 0.03 ; 1 ; 1),(0.01 ; 0.02 ; 0.02 ; 0.02 ; 0.9 ; 0.9))$ & $((0 ; 0 ; 0 ; 0.01 ; 1 ; 1),(0 ; 0 ; 0 ; 0.01 ; 0.9 ; 0.9))$ & $((0 ; 0 ; 0 ; 0.01 ; 1 ; 1),(0 ; 0 ; 0 ; 0.01 ; 0.9 ; 0.9))$ \\
\hline \multicolumn{4}{|c|}{$((0.01,0.02,0.02,0.00,1,1),(0.01,0.02,0.02,0.02,0.3,0.7))$} \\
\hline C61 & $((0 ; 0.01 ; 0.01 ; 0.02 ; 1 ; 1),(0.01 ; 0.01 ; 0.01 ; 0.01 ; 0.9 ; 0.9))$ & $((0.01 ; 0.01 ; 0.01 ; 0.02 ; 1 ; 1),(0.01 ; 0.01 ; 0.01 ; 0.02 ; 0.9 ; 0.9))$ & $((0.01 ; 0.02 ; 0.02 ; 0.03 ; 1 ; 1),(0.01 ; 0.02 ; 0.02 ; 0.02 ; 0.9 ; 0.9))$ \\
\hline C62 & $((0.02 ; 0.03 ; 0.03 ; 0.04 ; 1 ; 1),(0.02 ; 0.03 ; 0.03 ; 0.03 ; 0.9 ; 0.9))$ & $((0.03 ; 0.04 ; 0.04 ; 0.05 ; 1 ; 1),(0.03 ; 0.04 ; 0.04 ; 0.04 ; 0.9 ; 0.9))$ & $((0.03 ; 0.05 ; 0.05 ; 0.05 ; 1 ; 1),(0.04 ; 0.05 ; 0.05 ; 0.05 ; 0.9 ; 0.9))$ \\
\hline C63 & $((0 ; 0 ; 0 ; 0.01 ; 1 ; 1),(0 ; 0 ; 0 ; 0 ; 0.9 ; 0.9))$ & $((0 ; 0 ; 0 ; 0.01 ; 1 ; 1),(0 ; 0 ; 0 ; 0.01 ; 0.9 ; 0.9))$ & $((0 ; 0.01 ; 0.01 ; 0.01 ; 1 ; 1),(0 ; 0.01 ; 0.01 ; 0.01 ; 0.9 ; 0.9))$ \\
\hline
\end{tabular}


Table 6. Cont.

\begin{tabular}{cccc}
\hline Criteria & Supplier 1 & Supplier 2 & Supplier 3 \\
\hline C64 & $((0.02 ; 0.03 ; 0.03 ; 0.04 ; 1 ; 1),(0.03 ; 0.03 ; 0.03 ; 0.04 ; 0.9 ; 0.9))$ & $((0.02 ; 0.02 ; 0.02 ; 0.03 ; 1 ; 1),(0.02 ; 0.02 ; 0.02 ; 0.03 ; 0.9 ; 0.9))$ & $((0.01 ; 0.02 ; 0.02 ; 0.02 ; 1 ; 1),(0.01 ; 0.02 ; 0.02 ; 0.02 ; 0.9 ; 0.9))$ \\
C65 & $((0.04 ; 0.05 ; 0.05 ; 0.07 ; 1 ; 1),(0.05 ; 0.05 ; 0.05 ; 0.06 ; 0.9 ; 0.9))$ & $((0.01 ; 0.03 ; 0.03 ; 0.05 ; 1 ; 1),(0.02 ; 0.03 ; 0.03 ; 0.04 ; 0.9 ; 0.9))$ & $((0.02 ; 0.04 ; 0.04 ; 0.05 ; 1 ; 1),(0.03 ; 0.04 ; 0.04 ; 0.05 ; 0.9 ; 0.9))$ \\
C7 & & & \\
C71 & $((0 ; 0 ; 0 ; 0 ; 1 ; 1),(0 ; 0 ; 0 ; 0 ; 0.9 ; 0.9))$ & $((0 ; 0 ; 0 ; 0.01 ; 1 ; 1),(0 ; 0 ; 0 ; 0 ; 0.9 ; 0.9))$ & $((0 ; 0 ; 0 ; 0.01 ; 1 ; 1),(0 ; 0 ; 0 ; 0.01 ; 0.9 ; 0.9))$ \\
C72 & $((0 ; 0.01 ; 0.01 ; 0.01 ; 1 ; 1),(0.01 ; 0.01 ; 0.01 ; 0.01 ; 0.9 ; 0.9))$ & $((0 ; 0.01 ; 0.01 ; 0.01 ; 1 ; 1),(0 ; 0.01 ; 0.01 ; 0.01 ; 0.9 ; 0.9))$ & $((0 ; 0 ; 0 ; 0.01 ; 1 ; 1),(0 ; 0 ; 0 ; 0.01 ; 0.9 ; 0.9))$ \\
C73 & $((0 ; 0 ; 0 ; 0.01 ; 1 ; 1),(0 ; 0 ; 0 ; 0 ; 0.9 ; 0.9))$ & $((0 ; 0.01 ; 0.01 ; 0.01 ; 1 ; 1),(0.01 ; 0.01 ; 0.01 ; 0.01 ; 0.9 ; 0.9))$ & $((0.01 ; 0.01 ; 0.01 ; 0.01 ; 1 ; 1),(0.01 ; 0.01 ; 0.01 ; 0.01 ; 0.9 ; 0.9))$ \\
C74 & $((0 ; 0 ; 0 ; 0 ; 1 ; 1),(0 ; 0 ; 0 ; 0 ; 0.9 ; 0.9))$ & $((0 ; 0 ; 0 ; 0.01 ; 1 ; 1),(0 ; 0 ; 0 ; 0.01 ; 0.9 ; 0.9))$ & $((0 ; 0.01 ; 0.01 ; 0.01 ; 1 ; 1),(0 ; 0.01 ; 0.01 ; 0.01 ; 0.9 ; 0.9))$ \\
C75 & $((0 ; 0 ; 0 ; 0 ; 1 ; 1),(0 ; 0 ; 0 ; 0 ; 0.9 ; 0.9))$ & $((0 ; 0 ; 0 ; 0 ; 1 ; 1),(0 ; 0 ; 0 ; 0 ; 0.9 ; 0.9))$ & $((0 ; 0 ; 0 ; 0 ; 1 ; 1),(0 ; 0 ; 0 ; 0 ; 0.9 ; 0.9))$ \\
C76 & $((0 ; 0 ; 0 ; 0 ; 1 ; 1),(0 ; 0 ; 0 ; 0 ; 0.9 ; 0.9))$ & $((0 ; 0 ; 0 ; 0 ; 1 ; 1),(0 ; 0 ; 0 ; 0 ; 0.9 ; 0.9))$ & $((0 ; 0 ; 0 ; 0 ; 1 ; 1),(0 ; 0 ; 0 ; 0 ; 0.9 ; 0.9))$ \\
C77 & $((0 ; 0 ; 0 ; 0 ; 1 ; 1),(0 ; 0 ; 0 ; 0 ; 0.9 ; 0.9))$ & & \\
C8 & & & \\
C81 & $((0 ; 0 ; 0 ; 0 ; 1 ; 1),(0 ; 0 ; 0 ; 0 ; 0.9 ; 0.9))$ & $((0 ; 0 ; 0 ; 0.01 ; 0.01 ; 0.01 ; 1 ; 1),(0 ; 0.01 ; 0.01 ; 0.01 ; 0.9 ; 0.9))$ & \\
C82 & $((0 ; 0 ; 0 ; 0 ; 1 ; 1),(0 ; 0 ; 0 ; 0 ; 0.9 ; 0.9))$ & $((0 ; 0 ; 0 ; 0 ; 1 ; 1),(0 ; 0 ; 0 ; 0 ; 0.9 ; 0.9))$ & $((0 ; 0 ; 0 ; 0 ; 0 ; 1 ; 1),(0 ; 0 ; 0 ; 0 ; 0.9 ; 0.9))$ \\
C83 & $((0 ; 0 ; 0 ; 0 ; 1 ; 1),(0 ; 0 ; 0 ; 0 ; 0.9 ; 0.9))$ & $(0 ; 0 ; 0 ; 0 ; 1 ; 1),(0 ; 0 ; 0 ; 0 ; 0.9 ; 0.9))$ & $(0 ; 0 ; 0 ; 0 ; 1 ; 1),(0 ; 0 ; 0 ; 0 ; 0.9 ; 0.9))$ \\
C84 & $((0.01 ; 0.01 ; 0.01 ; 0.01 ; 1 ; 1),(0.01 ; 0.01 ; 0.01 ; 0.01 ; 0.9 ; 0.9))$ & $((0 ; 0.01 ; 0.01 ; 0.01 ; 1 ; 1),(0.01 ; 0.01 ; 0.01 ; 0.01 ; 0.9 ; 0.9))$ & $((0 ; 0 ; 0 ; 0 ; 1 ; 1),(0 ; 0 ; 0 ; 0 ; 0.9 ; 0.9))$ \\
C85 & $((0 ; 0 ; 0 ; 0.01 ; 1 ; 1),(0 ; 0 ; 0 ; 0 ; 0.9 ; 0.9))$ & $((0 ; 0.01 ; 0.01 ; 0.01 ; 1 ; 1),(0 ; 0.01 ; 0.01 ; 0.01 ; 0.9 ; 0.9))$ & $((0 ; 0.01 ; 0.01 ; 0.0 .01 ; 1 ; 1 ; 1),(0 ; 0 ; 0 ; 0.01 ; 0.9 ; 0.9))$ \\
C86 & $((0 ; 0 ; 0 ; 0 ; 1 ; 1),(0 ; 0 ; 0 ; 0 ; 0.9 ; 0.9))$ & $(0 ; 0.01 ; 0.01 ; 0.01 ; 0.01 ; 0.9 ; 0.0 .9))$ & $((0 ; 0 ; 0 ; 0 ; 1 ; 1),(0 ; 0 ; 0 ; 0 ; 0.9 ; 0.9))$ \\
\hline
\end{tabular}


Table 7. The rank values.

\begin{tabular}{|c|c|c|c|}
\hline Criteria & Supplier 1 & Supplier 2 & Supplier 3 \\
\hline \multicolumn{4}{|l|}{$\mathrm{C} 1$} \\
\hline C11 & 3.8147 & 3.8376 & 3.8530 \\
\hline $\mathrm{C} 12$ & 3.8036 & 3.8177 & 3.8177 \\
\hline $\mathrm{C} 13$ & 3.8458 & 3.9168 & 3.9403 \\
\hline $\mathrm{C} 14$ & 3.8091 & 3.8263 & 3.8263 \\
\hline C15 & 3.8300 & 3.8459 & 3.8459 \\
\hline $\mathrm{C} 16$ & 3.8634 & 3.9136 & 3.9297 \\
\hline C17 & 3.8372 & 3.8505 & 3.8639 \\
\hline \multicolumn{4}{|l|}{$\mathrm{C} 2$} \\
\hline $\mathrm{C} 21$ & 3.8508 & 3.8720 & 3.9042 \\
\hline $\mathrm{C} 22$ & 3.8127 & 3.8189 & 3.8257 \\
\hline $\mathrm{C} 23$ & 3.8293 & 3.8239 & 3.8240 \\
\hline $\mathrm{C} 24$ & 3.8065 & 3.8018 & 3.8018 \\
\hline $\mathrm{C} 25$ & 3.8039 & 3.8025 & 3.8025 \\
\hline $\mathrm{C} 26$ & 3.8222 & 3.8758 & 3.8715 \\
\hline \multicolumn{4}{|l|}{$\mathrm{C} 3$} \\
\hline C31 & 3.9839 & 4.0811 & 4.2033 \\
\hline C32 & 3.8700 & 3.9454 & 4.0087 \\
\hline $\mathrm{C} 33$ & 3.9362 & 3.9932 & 4.0206 \\
\hline C34 & 3.8348 & 3.8762 & 3.8762 \\
\hline \multicolumn{4}{|l|}{$\mathrm{C} 4$} \\
\hline C41 & 3.8450 & 3.8721 & 3.8678 \\
\hline $\mathrm{C} 42$ & 3.9169 & 3.9658 & 3.9893 \\
\hline $\mathrm{C} 43$ & 3.9931 & 3.9527 & 4.0737 \\
\hline \multicolumn{4}{|l|}{$\mathrm{C} 5$} \\
\hline C51 & 3.9373 & 3.9839 & 3.8920 \\
\hline C52 & 3.8124 & 3.8017 & 3.8094 \\
\hline C53 & 3.8268 & 3.8105 & 3.8029 \\
\hline C54 & 3.9548 & 3.8930 & 3.8607 \\
\hline C55 & 3.8162 & 3.8061 & 3.8123 \\
\hline C56 & 3.8237 & 3.8379 & 3.8379 \\
\hline C57 & 3.8977 & 3.8133 & 3.8133 \\
\hline \multicolumn{4}{|l|}{ C6 } \\
\hline C61 & 3.8479 & 3.8734 & 3.8967 \\
\hline C62 & 3.9663 & 4.0345 & 4.0692 \\
\hline C63 & 3.8215 & 3.8283 & 3.8357 \\
\hline C64 & 3.9895 & 3.9415 & 3.8926 \\
\hline C65 & 4.1179 & 3.9531 & 4.0080 \\
\hline \multicolumn{4}{|l|}{ C7 } \\
\hline C71 & 3.8144 & 3.8220 & 3.8258 \\
\hline C72 & 3.8382 & 3.8325 & 3.8269 \\
\hline C73 & 3.8181 & 3.8376 & 3.8539 \\
\hline C74 & 3.8143 & 3.8257 & 3.8293 \\
\hline C75 & 3.8043 & 3.8094 & 3.8099 \\
\hline C76 & 3.8095 & 3.8246 & 3.8232 \\
\hline C77 & 3.8165 & 3.8295 & 3.8252 \\
\hline \multicolumn{4}{|l|}{$\mathrm{C} 8$} \\
\hline C81 & 3.8062 & 3.8066 & 3.8066 \\
\hline C82 & 3.8005 & 3.8009 & 3.8017 \\
\hline C83 & 3.8031 & 3.8022 & 3.8031 \\
\hline C84 & 3.8516 & 3.8360 & 3.8235 \\
\hline C85 & 3.8148 & 3.8298 & 3.8377 \\
\hline C86 & 3.8068 & 3.8045 & 3.8045 \\
\hline
\end{tabular}


Hereafter, the positive ideal and negative ideal solutions are calculated for green suppliers. The closeness coefficient for each green supplier is computed and rankings are determined in decreasing order (Table 8). In IT2F TOPSIS, the larger the value of closeness coefficient, the higher the preference of the green supplier. We determined the greenest supplier as Supplier 3 based on five expert evaluations using the proposed BWM and IT2F TOPSIS model.

Table 8. The ranking of the supplier.

\begin{tabular}{cccc}
\hline Supplier & Supplier 1 & Supplier 2 & Supplier 3 \\
\hline$d^{+}$ & 0.3591 & 0.2839 & 0.2181 \\
$d^{-}$ & 0.2408 & 0.2334 & 0.3705 \\
CC & 0.4014 & 0.4512 & 0.6295 \\
\hline Rank & 3 & 2 & 1 \\
\hline
\end{tabular}

\subsection{The Comparative Analysis}

The proposed approach is compared with a benchmarking model to validate its effectiveness. This benchmarking model concerns with IT2F VIKOR. For both approaches, the importance weights of green supplier selection criteria are obtained from BWM. In the second phase of the model, both are applied to rank suppliers. Results of final scores and ranking orders of suppliers in this new benchmarking model are given in Table 9. According to Table 9, ranking orders of three suppliers remain the same with our proposed model (integrated BWM and IT2F TOPSIS) when maximum group utility value (v) is set to 0.5 or higher than 0.5 . This result demonstrates that the proposed approach yields reasonable results and presents suitable outcomes to decision-making in green supplier selection.

Table 9. Q values and rankings for each supplier in terms of v value change.

\begin{tabular}{ccccccc}
\hline \multirow{2}{*}{$\begin{array}{c}\text { Maximum Group Utility } \\
\text { Value }(\boldsymbol{v}) \text { in VIKOR }\end{array}$} & \multicolumn{3}{c}{ Q Value } & \multicolumn{3}{c}{ Rank } \\
\cline { 2 - 6 } & Supplier 1 & Supplier 2 & Supplier 3 & Supplier 1 & Supplier 2 & Supplier 3 \\
\hline $\mathrm{v}=0.1$ & 0.450 & 1.000 & 0.000 & 2 & 3 & 1 \\
$\mathrm{v}=0.1$ & 0.505 & 0.934 & 0.000 & 2 & 3 & 1 \\
$\mathrm{v}=0.2$ & 0.560 & 0.869 & 0.000 & 2 & 3 & 1 \\
$\mathrm{v}=0.3$ & 0.615 & 0.803 & 0.000 & 2 & 3 & 1 \\
$\mathrm{v}=0.4$ & 0.670 & 0.738 & 0.000 & 2 & 3 & 1 \\
$\mathrm{v}=0.5$ & 0.725 & 0.672 & 0.000 & 3 & 2 & 1 \\
$\mathrm{v}=0.6$ & 0.780 & 0.607 & 0.000 & 3 & 2 & 1 \\
$\mathrm{v}=0.7$ & 0.835 & 0.541 & 0.000 & 3 & 2 & 1 \\
$\mathrm{v}=0.8$ & 0.890 & 0.475 & 0.000 & 3 & 2 & 1 \\
$\mathrm{v}=0.9$ & 0.945 & 0.410 & 0.000 & 3 & 2 & 1 \\
$\mathrm{v}=1.0$ & 1.000 & 0.344 & 0.000 & 3 & 2 & 1 \\
\hline
\end{tabular}

\section{Conclusions}

Selection of suppliers under green concept is a significant milestone for organizations that are moving towards a more environmental supply chain. In today's world, organizations are following new ways to reduce negative effects of their organizations to the environment and to reach a greener system. At this point, green supplier selection concept has gained great importance with its ability to incorporate environmental or green criteria into the classical supplier selection practices. In the literature, lots of approaches are proposed regarding supplier selection and green supplier selection. Integration of fuzzy set theory and its various versions with classical MCDM methods is the forefront in the modeling of green supplier selection.

Therefore, in this study, we propose a multi-phase approach for green supplier selection. First, the selection of criteria under green motivation through literature review and interviews with decision-makers is performed. In the second phase, weights of green supplier selection criteria are determined using BWM. Finally, to obtain ranking order of suppliers with respect to previously 
weighted criteria, an IT2F TOPSIS method is used. Moreover, a comparative study between the proposed approach and BWM-IT2F VIKOR is provided to validate effectiveness of the proposed approach. This study is considered as the first attempt in the literature that integrates BWM and IT2F TOPSIS. BWM is preferred in weighting the selection criteria since it is more efficient and easier for pairwise comparisons versus Analytic Hierarchy Process. Use of TOPSIS method extended with IT2FSs enables reflecting more uncertainty and ambiguity in the decision-making process as well as including a concept of similarity to ideal solution. The proposed multi-phase approach is applied to the green supplier selection process in a plastic injection molding facility in Turkey.

The proposed approach with its case study has also some limitations. First concerns the integrated methodology.

This study proposes an incorporation of BWM and IT2F TOPSIS for green supplier selection. However, other MCDM methods like VIKOR, PROMETHEE and Elimination Et Choix Traduisant la Realité (ELECTRE) can also be used for this study. Moreover, different versions of fuzzy set theory that have recently been popular, such as Pythagorean fuzzy sets, hesitant fuzzy sets and intuitionistic fuzzy sets, can also be applied to our case study. Secondly, in this study the case study in a single facility has been taken. Therefore, the proposed approach can be adapted from this facility or industry to another one. Future attempts can include the following: (1) A comparative framework can be developed that can highlight the optimal method in selection of green suppliers. (2) A broader and multi-facility data can be used in the problem.

Author Contributions: All authors contributed equally.

Funding: No specific funding was received for this study.

Acknowledgments: The authors would like to thank the worthy referees and editor for their valuable suggestions for our paper in Mathematics.

Conflicts of Interest: The authors declare no conflict of interest.

\section{References}

1. Ketikidis, P.H.; Koh, S.C.L.; Dimitriadis, N.; Gunasekaran, A.; Kehajova, M. The use of information systems for logistics and supply chain management in South East Europe: Current status and future direction. Omega 2008, 36, 592-599. [CrossRef]

2. Coulson-Thomas, C. The knowledge entrepreneurship challenge: Moving on from knowledge sharing to knowledge creation and exploitation. Learn. Organ. 2004, 11, 84. [CrossRef]

3. Wang, C.N.; Nguyen, V.T.; Thai, H.T.N.; Tran, N.N.; Tran, T.L.A. Sustainable Supplier Selection Process in Edible Oil Production by a Hybrid Fuzzy Analytical Hierarchy Process and Green Data Envelopment Analysis for the SMEs Food Processing Industry. Mathematics 2018, 6, 302. [CrossRef]

4. Yücenur, G.N.; Vayvay, Ö.; Demirel, N.Ç. Supplier selection problem in global supply chains by AHP and ANP approaches under fuzzy environment. Int. J. Adv. Manuf. Technol. 2011, 56, 823-833. [CrossRef]

5. Kim, J.S.; Jeon, E.; Noh, J.; Park, J.H. A Model and an Algorithm for a Large-Scale Sustainable Supplier Selection and Order Allocation Problem. Mathematics 2018, 6, 325. [CrossRef]

6. Zhu, Q.; Dou, Y.; Sarkis, J. A portfolio-based analysis for green supplier management using the analytical network process. Supply Chain Manag. Int. J. 2010, 15, 306-319. [CrossRef]

7. ElTayeb, T.K.; Zailani, S.; Jayaraman, K. The examination on the drivers for green purchasing adoption among EMS 14001 certified companies in Malaysia. J. Manuf. Technol. Manag. 2010, 21, 206-225. [CrossRef]

8. Tian, C.; Zhang, W.; Zhang, S.; Peng, J. An Extended Single-Valued Neutrosophic Projection-Based Qualitative Flexible Multi-Criteria Decision-Making Method. Mathematics 2019, 7, 39. [CrossRef]

9. Liu, P.; Chen, S.M. Multiattribute group decision making based on intuitionistic 2-tuple linguistic information. Inf. Sci. 2018, 430, 599-619. [CrossRef]

10. Liu, P.; Chen, S.M. Group decision making based on Heronian aggregation operators of intuitionistic fuzzy numbers. IEEE Trans. Cybern. 2017, 47, 2514-2530. [CrossRef]

11. Liu, P.; Liu, J.; Merigó, J.M. Partitioned Heronian means based on linguistic intuitionistic fuzzy numbers for dealing with multi-attribute group decision making. Appl. Soft Comput. 2018, 62, 395-422. [CrossRef] 
12. Liu, P.; Wang, P. Some q-rung orthopair fuzzy aggregation operators and their applications to multiple-attribute decision making. Int. J. Intell. Syst. 2018, 33, 259-280. [CrossRef]

13. Banaeian, N.; Mobli, H.; Fahimnia, B.; Nielsen, I.E.; Omid, M. Green supplier selection using fuzzy group decision making methods: A case study from the agri-food industry. Comput. Oper. Res. 2018, 89, 337-347. [CrossRef]

14. Hlioui, R.; Gharbi, A.; Hajji, A. Joint supplier selection, production and replenishment of an unreliable manufacturing-oriented supply chain. Int. J. Prod. Econ. 2017, 187, 53-67. [CrossRef]

15. Yu, F.; Yang, Y.; Chang, D. Carbon footprint based green supplier selection under dynamic environment. J. Clean. Prod. 2018, 170, 880-889. [CrossRef]

16. Kannan, D.; Govindan, K.; Rajendran, S. Fuzzy Axiomatic Design approach based green supplier selection: A case study from Singapore. J. Clean. Prod. 2015, 96, 194-208. [CrossRef]

17. Rezaei, J. Best-worst multi-criteria decision-making method: Some properties and a linear model. Omega 2016, 64, 126-130. [CrossRef]

18. Govindan, K.; Sivakumar, R. Green supplier selection and order allocation in a low-carbon paper industry: Integrated multi-criteria heterogeneous decision making and multi-objective linear programming approaches. Ann. Oper. Res. 2016, 238, 243-276. [CrossRef]

19. Yazdani, M.; Chatterjee, P.; Zavadskas, E.K.; Zolfani, S.H. Integrated QFD-MCDM framework for green supplier selection. J. Clean. Prod. 2017, 142, 3728-3740. [CrossRef]

20. Hu, Z.; Rao, C.; Zheng, Y.; Huang, D. Optimization decision of supplier selection in green procurement under the mode of low carbon economy. Int. J. Comput. Intell. Syst. 2015, 8, 407-421. [CrossRef]

21. Shabanpour, H.; Yousefi, S.; Saen, R.F. Forecasting efficiency of green suppliers by dynamic data envelopment analysis and artificial neural networks. J. Clean. Prod. 2017, 142, 1098-1107. [CrossRef]

22. Quan, M.Y.; Wang, Z.L.; Liu, H.C.; Shi, H. A hybrid MCDM approach for large group green supplier selection with uncertain linguistic information. IEEE Access 2018, 6, 50372-50383. [CrossRef]

23. Dou, Y.; Zhu, Q.; Sarkis, J. Evaluating green supplier development programs with a grey-analytical network process-based methodology. Eur. J. Oper. Res. 2014, 233, 420-431. [CrossRef]

24. Tsui, C.W.; Tzeng, G.H.; Wen, U.P. A hybrid MCDM approach for improving the performance of green suppliers in the TFT-LCD industry. Int. J. Prod. Res. 2015, 53, 6436-6454. [CrossRef]

25. Hashemi, S.H.; Karimi, A.; Tavana, M. An integrated green supplier selection approach with analytic network process and improved Grey relational analysis. Int. J. Prod. Econ. 2015, 159, 178-191. [CrossRef]

26. Uygun, Ö.; Dede, A. Performance evaluation of green supply chain management using integrated fuzzy multi-criteria decision making techniques. Comput. Ind. Eng. 2016, 102, 502-511. [CrossRef]

27. Govindan, K.; Rajendran, S.; Sarkis, J.; Murugesan, P. Multi criteria decision making approaches for green supplier evaluation and selection: A literature review. J. Clean. Prod. 2015, 98, 66-83. [CrossRef]

28. Malviya, R.K.; Kant, R. Green supply chain management (GSCM): A structured literature review and research implications. Benchmark. Int. J. 2015, 22, 1360-1394. [CrossRef]

29. Rezaei, J. Best-worst multi-criteria decision-making method. Omega 2015, 53, 49-57. [CrossRef]

30. Rezaei, J.; Wang, J.; Tavasszy, L. Linking supplier development to supplier segmentation using Best Worst Method. Expert Syst. Appl. 2015, 42, 9152-9164. [CrossRef]

31. Rezaei, J.; Nispeling, T.; Sarkis, J.; Tavasszy, L. A supplier selection life cycle approach integrating traditional and environmental criteria using the best worst method. J. Clean. Prod. 2016, 135, 577-588. [CrossRef]

32. Gupta, H.; Barua, M.K. Supplier selection among SMEs on the basis of their green innovation ability using BWM and fuzzy TOPSIS. J. Clean. Prod. 2017, 152, 242-258. [CrossRef]

33. Mou, Q.; Xu, Z.; Liao, H. An intuitionistic fuzzy multiplicative best-worst method for multi-criteria group decision making. Inf. Sci. 2016, 374, 224-239. [CrossRef]

34. Rezaei, J.; Hemmes, A.; Tavasszy, L. Multi-criteria decision-making for complex bundling configurations in surface transportation of air freight. J. Air Transp. Manag. 2017, 61, 95-105. [CrossRef]

35. Ahmad, W.N.K.W.; Rezaei, J.; Sadaghiani, S.; Tavasszy, L.A. Evaluation of the external forces affecting the sustainability of oil and gas supply chain using best worst method. J. Clean. Prod. 2017, 153, $242-252$. [CrossRef]

36. Guo, S.; Zhao, H. Fuzzy best-worst multi-criteria decision-making method and its applications. Knowl.-Based Syst. 2017, 121, 23-31. [CrossRef] 
37. Van de Kaa, G.; Kamp, L.; Rezaei, J. Selection of biomass thermochemical conversion technology in the Netherlands: A best worst method approach. J. Clean. Prod. 2017, 166, 32-39. [CrossRef]

38. Omrani, H.; Alizadeh, A.; Emrouznejad, A. Finding the optimal combination of power plants alternatives: A multi response Taguchi-neural network using TOPSIS and fuzzy best-worst method. J. Clean. Prod. 2018, 203, 210-223. [CrossRef]

39. Nielsen, I.E.; Banaeian, N.; Golińska, P.; Mobli, H.; Omid, M. Green supplier selection criteria: From a literature review to a flexible framework for determination of suitable criteria. In Logistics Operations, Supply Chain Management and Sustainability; Springer: Cham, Switzerland, 2014; pp. 79-99.

40. Kahraman, C.; Engin, O.; Kabak, Ö.; Kaya, İ. Information systems outsourcing decisions using a group decision-making approach. Eng. Appl. Artif. Intell. 2009, 22, 832-841. [CrossRef]

41. Büyüközkan, G.; Çifçi, G. A novel fuzzy multi-criteria decision framework for sustainable supplier selection with incomplete information. Comput. Ind. 2010, 62, 164-174. [CrossRef]

42. Chiou, C.Y.; Hsu, C.W.; Hwang, W.Y. Comparative investigation on green supplier selection of the American, Japanese and Taiwanese electronics industry in China. In Proceedings of the IEEE International Conference on Industrial Engineering and Engineering Management (IEEM 2008), Singapore, 8-11 December 2008; pp. 1909-1914.

43. Demirtas, E.A.; Ustun, O. Analytic network process and multi-period goal programming integration in purchasing decisions. Comput. Ind. Eng. 2009, 56, 677-690. [CrossRef]

44. Lee, A.H. A fuzzy supplier selection model with the consideration of benefits, opportunities, costs and risks. Expert Syst. Appl. 2009, 36, 2879-2893. [CrossRef]

45. Lin, Y.T.; Lin, C.L.; Yu, H.C.; Tzeng, G.H. A novel hybrid MCDM approach for outsourcing vendor selection: A case study for a semiconductor company in Taiwan. Expert Syst. Appl. 2010, 37, 4796-4804. [CrossRef]

46. Liou, J.J.; Chuang, Y.T. Developing a hybrid multi-criteria model for selection of outsourcing providers. Expert Syst. Appl. 2010, 37, 3755-3761. [CrossRef]

47. Liu, J.; Ding, F.Y.; Lall, V. Using data envelopment analysis to compare suppliers for supplier selection and performance improvement. Supply Chain Manag. Int. J. 2000, 5, 143-150. [CrossRef]

48. Liu, T.; Deng, Y.; Chan, F. Evidential supplier selection based on DEMATEL and game theory. Int. J. Fuzzy Syst. 2018, 20, 1321-1333. [CrossRef]

49. Luthra, S.; Govindan, K.; Kannan, D.; Mangla, S.K.; Garg, C.P. An integrated framework for sustainable supplier selection and evaluation in supply chains. J. Clean. Prod. 2017, 140, 1686-1698. [CrossRef]

50. Malmir, R.; Hamzehi, E.; Farsijani, H. A Multi stage decision making model to evaluate suppliers by using MOLP and ANP in a strategic approach. Int. J. Appl. Innov. Eng. Manag. 2013, 2, 563-577.

51. Razmi, J.; Rafiei, H.; Hashemi, M. Designing a decision support system to evaluate and select suppliers using fuzzy analytic network process. Comput. Ind. Eng. 2009, 57, 1282-1290. [CrossRef]

52. Da Silva, A.S.; Nascimento, L.P.A.; Ribeiro, J.R.; Belderrain, M.C.N. ANP and ratings model applied to supplier selection problem. In Proceedings of the International Symposium on the AHP, Pittsburgh, PA, USA, 29 July-1 August 2009; pp. 1-14.

53. Vinodh, S.; Ramiya, R.A.; Gautham, S.G. Application of fuzzy analytic network process for supplier selection in a manufacturing organisation. Expert Syst. Appl. 2011, 38, 272-280. [CrossRef]

54. Wadhwa, V.; Ravindran, A.R. Vendor selection in outsourcing. Comput. Oper. Res. 2007, 34, 3725-3737. [CrossRef]

55. Wang, J.W.; Cheng, C.H.; Huang, K.C. Fuzzy hierarchical TOPSIS for supplier selection. Appl. Soft Comput. 2009, 9, 377-386. [CrossRef]

56. Attari, M.Y.N.; Bagheri, M.; Jami, E.N. A decision making model for outsourcing of manufacturing activities by ANP and DEMATEL under fuzzy environment. Int. J. Ind. Eng. 2012, 23, 163-174.

57. Haq, A.N.; Kannan, G. Fuzzy analytical hierarchy process for evaluating and selecting a vendor in a supply chain model. Int. J. Adv. Manuf. Technol. 2006, 29, 826-835.

58. Prahinski, C.; Benton, W.C. Supplier evaluations: Communication strategies to improve supplier performance. J. Oper. Manag. 2004, 22, 39-62. [CrossRef]

59. Freeman, J.; Chen, T. Green supplier selection using an AHP-Entropy-TOPSIS framework. Supply Chain Manag. Int. J. 2015, 20, 327-340. [CrossRef]

60. Hsu, C.W.; Kuo, T.C.; Chen, S.H.; Hu, A.H. Using DEMATEL to develop a carbon management model of supplier selection in green supply chain management. J. Clean. Prod. 2013, 56, 164-172. [CrossRef] 
61. Kuo, R.J.; Wang, Y.C.; Tien, F.C. Integration of artificial neural network and MADA methods for green supplier selection. J. Clean. Prod. 2010, 18, 1161-1170. [CrossRef]

62. Celik, E.; Gul, M.; Gumus, A.T.; Guneri, A.F. A fuzzy TOPSIS approach based on trapezoidal numbers to material selection problem. J. Inf. Technol. Appl. Manag. 2012, 19, 19-30.

63. Behzadian, M.; Otaghsara, S.K.; Yazdani, M.; Ignatius, J. A state-of the-art survey of TOPSIS applications. Expert Syst. Appl. 2012, 39, 13051-13069. [CrossRef]

64. Yoon, K.P.; Hwang, C.L. Multiple Attribute Decision Making: An Introduction; Sage Publications: Thousand Oaks, CA, USA, 1995; Volume 104.

65. Chen, S.M.; Lee, L.W. Fuzzy multiple attributes group decision-making based on the interval type-2 TOPSIS method. Expert Syst. Appl. 2010, 37, 2790-2798. [CrossRef]

66. Oz, N.E.; Mete, S.; Serin, F.; Gul, M. Risk assessment for clearing and grading process of a natural gas pipeline project: An extended TOPSIS model with Pythagorean fuzzy sets for prioritizing hazards. Hum. Ecol. Risk Assess. Int. J. 2018, 1-18. [CrossRef]

67. Ak, M.F.; Gul, M. AHP-TOPSIS integration extended with Pythagorean fuzzy sets for information security risk analysis. Complex Intell. Syst. 2018. [CrossRef]

68. Celik, E.; Bilisik, O.N.; Erdogan, M.; Gumus, A.T.; Baracli, H. An integrated novel interval type-2 fuzzy MCDM method to improve customer satisfaction in public transportation for Istanbul. Transp. Res. Part E: Logist. Transp. Rev. 2013, 58, 28-51. [CrossRef]

69. Celik, E.; Aydin, N.; Gumus, A.T. A multiattribute customer satisfaction evaluation approach for rail transit network: A real case study for Istanbul, Turkey. Transp. Policy 2014, 36, 283-293. [CrossRef]

70. Celik, E.; Gumus, A.T.; Alegoz, M. A trapezoidal type-2 fuzzy MCDM method to identify and evaluate critical success factors for humanitarian relief logistics management. J. Intell. Fuzzy Syst. 2014, 27, 2847-2855.

71. Celik, E.; Gul, M.; Aydin, N.; Gumus, A.T.; Guneri, A.F. A comprehensive review of multi criteria decision making approaches based on interval type-2 fuzzy sets. Knowl.-Based Syst. 2015, 85, 329-341. [CrossRef]

72. Celik, E.; Gumus, A.T. An assessment approach for non-governmental organizations in humanitarian relief logistics and an application in Turkey. Technol. Econ. Dev. Econ. 2018, 24, 1-26. [CrossRef]

73. Madan, J.; Mani, M.; Lee, J.H.; Lyons, K.W. Energy performance evaluation and improvement of unit-manufacturing processes: Injection molding case study. J. Clean. Prod. 2015, 105, 157-170. [CrossRef]

(C) 2019 by the authors. Licensee MDPI, Basel, Switzerland. This article is an open access article distributed under the terms and conditions of the Creative Commons Attribution (CC BY) license (http:/ / creativecommons.org/licenses/by/4.0/). 